\title{
An ingenious non-spherical mesoporous silica nanoparticle cargo with curcumin induces mitochondria-mediated apoptosis in breast cancer (MCF-7) cells
}

\author{
Lakshminarasimhan Harini ${ }^{1}$, Sweta Srivastava ${ }^{2}$, George Peter Gnanakumar ${ }^{3}$, Bose \\ Karthikeyan ${ }^{1,4}$, Cecil Ross ${ }^{5}$, Vaithilingam Krishnakumar6, Velu Rajesh Kannan ${ }^{6}$, \\ Krishnan Sundar ${ }^{1,7}$ and Thandavarayan Kathiresan ${ }^{1,7}$ \\ ${ }^{1}$ Department of Biotechnology, Kalasalingam University, Krishnankoil, Tamil Nadu, India \\ ${ }^{2}$ Department of Translation Medicine, St. Johns National Academy of Health Sciences, Bangalore, Karnataka, India \\ ${ }^{3}$ School of Physical Chemistry, Madurai Kamaraj University, Madurai, Tamil Nadu, India \\ ${ }^{4}$ Oregon Health and Science University, Knight Cardiovascular Institute (KCVI), Portland, Oregon, USA \\ ${ }^{5}$ Department of Medicine, St. Johns National Academy of Health Sciences, Bangalore, Karnataka, India \\ ${ }^{6}$ Department of Microbiology, Bharathidasan University, Tiruchirappalli, Tamil Nadu, India \\ ${ }^{7}$ International Research Centre, Kalasalingam University, Krishnankoil, Tamil Nadu, India \\ Correspondence to: Thandavarayan Kathiresan, email: t.kathiresan@klu.ac.in
}

Keywords: caspase; mesoporous silica nanoparticle; toxicity; mitochondria; doxorubicin

Received: July 25, $2018 \quad$ Accepted: January 12, $2019 \quad$ Published: February 05, 2019

Copyright: Harini et al. This is an open-access article distributed under the terms of the Creative Commons Attribution License 3.0 (CC BY

3.0), which permits unrestricted use, distribution, and reproduction in any medium, provided the original author and source are credited.

ABSTRACT

Curcumin delivery to cancer cells is challenging due to its hydrophobic nature, low bio distribution and low availability. Many nano vehicles suffer from low stability and toxicity, and hence the prerequisite of a non-toxic nano vehicle with effective drug delivery is still being delved. The present study investigates the delivery efficiency of curcumin with non-spherical mesoporous silica nanoparticles (MSNAs). Their mechanism of drug delivery and signalling proteins activated to induce apoptosis was further explored in MCF-7 cells. A non-spherical MSN was synthesised, functionalised with PEI (MSNAP) and analysed its intracellular behaviour. Our result indicates that MSNAP was non-toxic until $20 \mu \mathrm{g} / \mathrm{mL}$ and likely localizes in cytoplasmic vesicles. On contrast, well-known MCM-41P induced autophagosome formation, indicating cellular toxicity. Curcumin was loaded on MSNAP and its effectiveness in inducing cell death was studied in MCF-7 and in MCF-7R cells. Curcumin loading on MSNAP induces better cell death with $30 \mu \mathrm{M}$ curcumin, better than unbounded curcumin. Western blot analysis suggest, curcumin induce apoptosis through the activation of caspase 9, 6, 12, PARP, CHOP and PTEN. The cell survival protein Akt1 was downregulated by curcumin with and without the nanostructure. Interestingly, cleaved caspase 9 was activated in higher amount in nano-conjugated curcumin compared to the free curcumin. But other ER resident protein like IRE1a, PERK and GRP78 were downregulated indicating curcumin disturbs ER homeostasis. Further, electron microscopic analysis reveled that nanocurcumin induced apoptosis by disrupting mitochondria and nucleus. Our results with doxorubicin resistant MCF-7 cell lines confirm nanodelivery of doxorubicin and curcumin sensitised cells effectively at lesser concentration. Further docking studies of curcumin indicate it interacts with the apoptotic proteins through hydrogen bonding formation and with higher binding energy. 


\section{INTRODUCTION}

Mesoporous silica nanoparticles have attained importance in biomedical research as a prominent drug delivery system (DDS). MSN's more flexibility in designing, fabricating and site-specific targeting enables enhanced encapsulation of the drug [1]. Moreover, its biocompatibility, alterable porosity, controlled drug release; high cargo loading and stability emphasize the prominence of MSN in drug delivery research [2]. Surface coating of nanoparticle with polymer enhances its retention time, biocompatibility and prevents aggregation $[3,4]$. Polymers like PEG, PCL, dextran, chitosan, PEI were widely used for nanoparticle sheathing, of which PEI, the cationic polymer is an efficient system for transfecting nucleic acid [5]. The 'proton sponge' effect of PEI aids its endosomal escape where most of the nanostructures are trapped [6]. Also PEI coating of nanostructures aids in efficient drug encapsulation and drug delivery in the cytosol [7]. PEI has efficient drug uptake and intracellular drug release but its application is limited due to cytotoxic nature.

Non-spherical nanoparticles are reported to be advantageous than the spherical nanoparticles in their compatibility, cellular uptake, biodistribution, longer circulation time, tumour accumulation, endosomal escape and tumour inhibition [8-10]. Toxicity of the nanoparticle is attributed to the induction of ROS which leads to oxidative DNA damage, membrane blabbing, protein adducts and enzyme dysfunction [11]. The high aspect ratio of long rods of MSN is less and also has reduced ROS production toxic when compared to short rods [12]. In contrary, in vivo study revealed that long rods are excreted less compared to the spherical particle which induced renal damage and hemorrhage [13]. Still, the effect of non-spherical MSN on cellular toxicity is debated at minimum level.

Though curcumin exhibits anticancer effect against many cancer cell lines, its poor solubility and stability fortify curcumin as the first drug of choice in nanoformulation [14]. So far, curcumin has been conjugated with liposomes, PLGA, cyclodextrin, micelles, dendrimers, polymers, metal oxides, carbon nanotubes, nanogels iron oxide and silica [15]. In spite of showing advantageous in curcumin delivery, each method had its own drawback. For instance, liposomal curcumin accumulate in liver and spleen due to low circulatory time in blood and also lack tissue specificity [16], PLGA with $\mathrm{N}$-isopropylacrylamide NPs curcumin formulation encapsulate multiple particles and solid lipid nanoparticlecurcumin lacked stability and could not be stored for longer time [17].

Mitochondria and endoplasmic reticulum plays a major role in progression of cancer. Both these organelles sense cellular stress in cancer microenvironment and modify their structure and function depending on cellular demand for cancer cell survival [18]. Thus, mitochondria are considered as the prime target for an anti-cancer investigation [19]. Curcumin nanoformulation of guanidine functionalized PEGylated mesoporous silica nanoparticle was effective inducing apoptosis in human breast adenocarcinoma cells (MCF-7), and mouse breast cancer cells (4T1), but not in human mammary epithelial cells (MCF-10A) [20]. Similarly, curcumin loaded on nanoformulations like Myristic acid (MA)-Chitosan nanogel [21], amine-functionalized KIT-6, MSU-2, and MCM-41 with curcumin induces cell death [22] in MBAMB-231 and A549 cell lines [22]. However, the detailed mechanism of nanocurcumin induced apoptosis remains elusive in cancer cells.

The present investigation elucidates PEI decorated non-spherical mesoporous silica nanoparticle (MSNAP) loaded with curcumin-induced apoptosis in both MCF7 and MCF-7R cells. Our results indicated that MSNAP was non-toxic and accumulate rapidly intracellular in MCF-7 cells. Curcumin released from CUR-MSNAP intracellularly induced apoptosis through disturbing mitochondria and nucleus in breast cancer MCF-7 cells in vitro. In MCF-7R cells, DOX-MSNAP induces cell death at a lesser concentration than unbound doxorubicin. Nontoxicity, faster intracellular accumulation, and effective intracellular drug delivery signify MSNAP as better drug delivery vehicle in vitro.

\section{RESULTS}

\section{MSNAP synthesis and biophysical characterisation}

MSNA was synthesized, coated with PEI and characterized for its structure and functional groups. PEI was coated on these silica particles through the electrostatic interaction between the $\mathrm{NH}^{+}, \mathrm{NH}_{2}^{+}$and $\mathrm{NH}_{3}{ }^{+}$ions of PEI and $\mathrm{Si}-\mathrm{OH}, \mathrm{Si}-\mathrm{O}-\mathrm{Si}, \mathrm{O}-\mathrm{Si}-\mathrm{O}$ anions of silica nanoparticles (Figure 1A). Similarly, curcumin loading on MSNAP was mediated by the electrostatic interaction between the PEI cationic groups and $-\mathrm{OH}$ and $-\mathrm{C}=\mathrm{O}$ anionic group of curcumin. SEM image of CURMSNAP confirms (Figure 1B) the non-spherical shaped discoid nanostructures. The rough surface (inset) of CURMSNAP indicates curcumin cargo on it. Further, TEM image (Figure 1C) confirms the pores of the nanoparticle are saturated by the drug. EDAX data (Figure 1D) revealed that CUR-MSNAP was composed of $\mathrm{Si}-15.15 \%$, $\mathrm{O}-41.15 \%, \mathrm{C}-35 \%$ and $\mathrm{N}-8.49 \%$. Presence of carbon confirms the loaded curcumin and nitrogen indicate the surface functionalization with PEI.

TEM analysis of MSNAP (data not shown), revealed the parallel arrangement of pores and variation in particle shape. TEM image of CUR-MSNAP (Figure 1C) appeared darker compared to MSNAP. Curcumin saturated the pores of MSNAP resulting in a darker image. 


\section{Drug uptake and release by MSNAP}

Drug adsorption studies were performed to determine the drug loading capacity of these nanostructures. Curcumin loading on MSNA was 20\% however, PEI coated MSNA enhanced the drug loading to $80 \%$ (Figure 1E). Therefore, PEI enhanced the capacity of drug loading in MSNAP to four-fold (Figure 1E). The release of curcumin from CUR-MSNAP was monitored in PBS at $\mathrm{pH} 7.4$ at various time points from 0 to $96 \mathrm{~h}$ (Figure 1F). A maximum of $23 \mu \mathrm{M}$ was released from CUR-MSNAP at $96 \mathrm{~h}$. In the initial 'burst phase' within $24 \mathrm{~h}$. CUR-MSNAP released $13 \mu \mathrm{M}$ of drug and then a sustained pattern of release was observed till $96 \mathrm{~h}$.
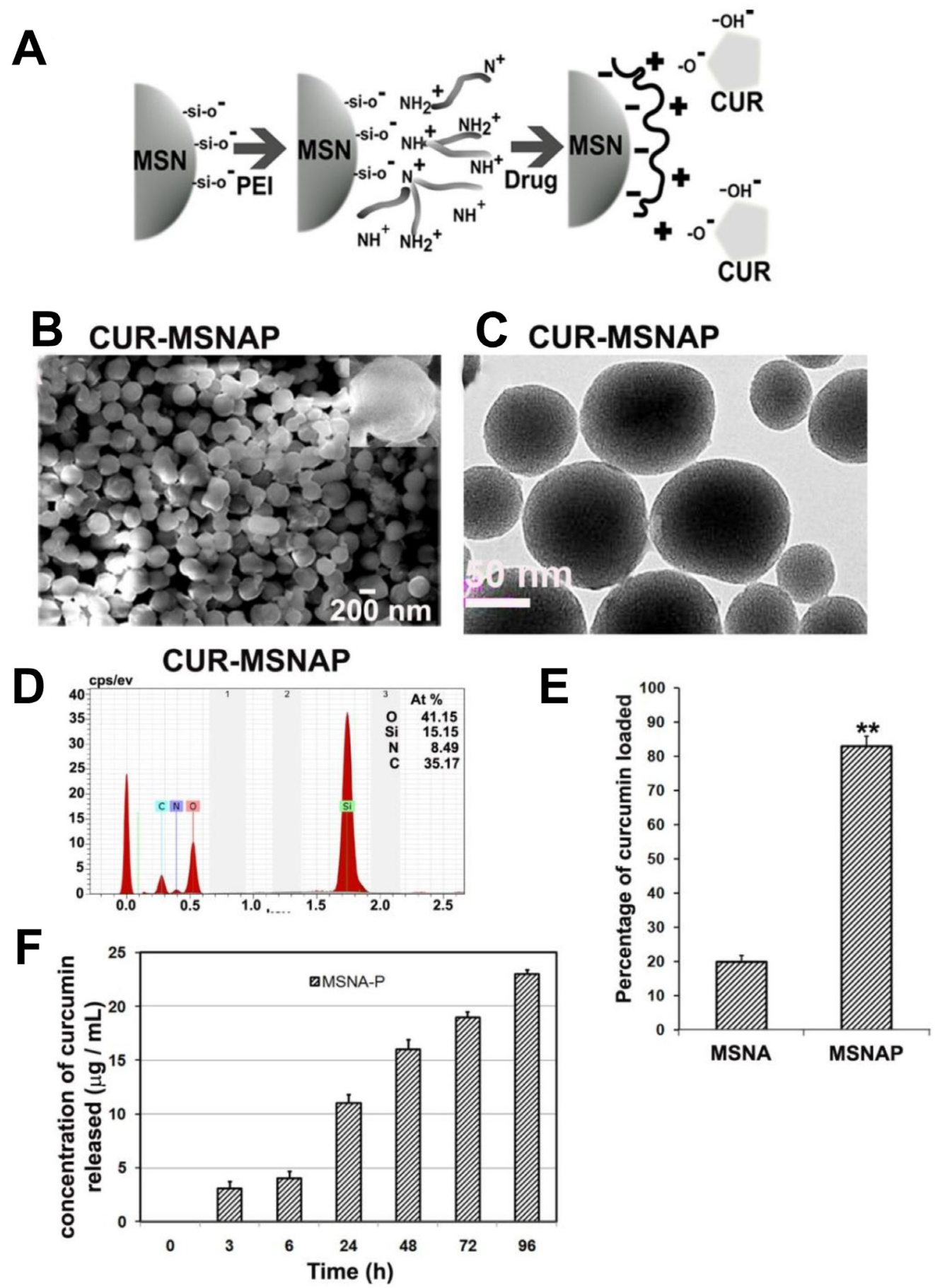

Figure 1: Characterization of CUR-MSNAP. (A) Schematic representation of PEI coating and curcumin loading on MSN (B) 200 nm scale SEM images curcumin-loaded MSNAP, inset: single CUR-MSNAP (C) $50 \mathrm{~nm}$ scale TEM images of CUR-MSNAP (D) EDAX graph of CUR-MSNAP (E) Graph of curcumin loading percentage on MSNAP (F) Graph of curcumin released at different time point from CUR-MSNAP at $\mathrm{pH} 7.4 . n=3,{ }^{* *}$ indicates $p<0.01$ of percentage of curcumin loaded on MSNAP compared to MSNA. 


\section{Toxicity evaluation of MSNAP in MCF-7 cells}

Toxicity of nanoparticles against $\mathrm{MCF}-7$ cells assessed with WST assay indicates $\mathrm{LD}_{50}$ of MCM-41P was $10 \mu \mathrm{g} / \mathrm{mL}$ (Figure 2A) however; the $\mathrm{LD}_{50}$ of MSNAP was $80 \mu \mathrm{g} / \mathrm{mL}$ (Figure 2B) after $24 \mathrm{~h}$. MSNAP was non-toxic until $20 \mu \mathrm{g} / \mathrm{mL}$ and even at $60 \mu \mathrm{g} / \mathrm{mL}$, MSNAP induced $10 \%$ of cell death. Hence a non-toxic concentration of $30 \mu \mathrm{g} / \mathrm{mL}$ was used in further experiments.

Time point accumulation study (Figure 2C), suggest MCF-7 cells uptake DOX-MCM-41P from 60 min. and a maximum saturation of nanoparticles was

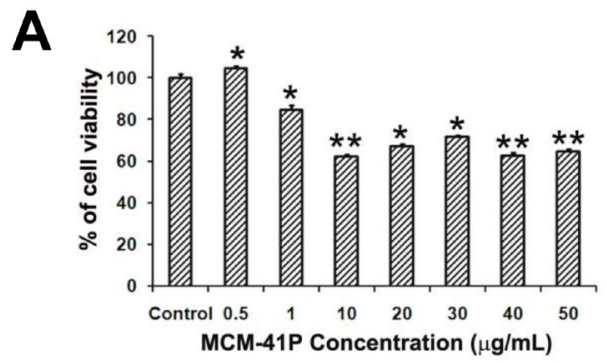

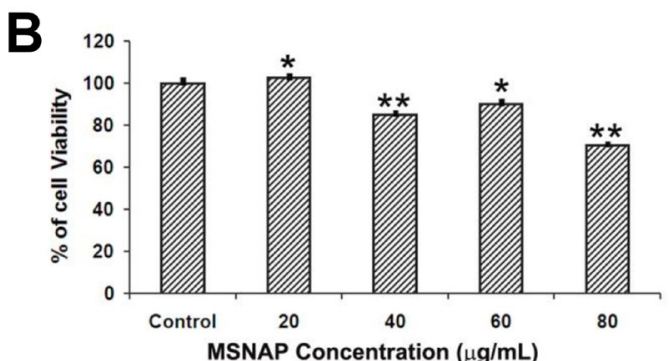

MSNAP Concentration $(\mu \mathrm{g} / \mathrm{mL})$

\section{C}

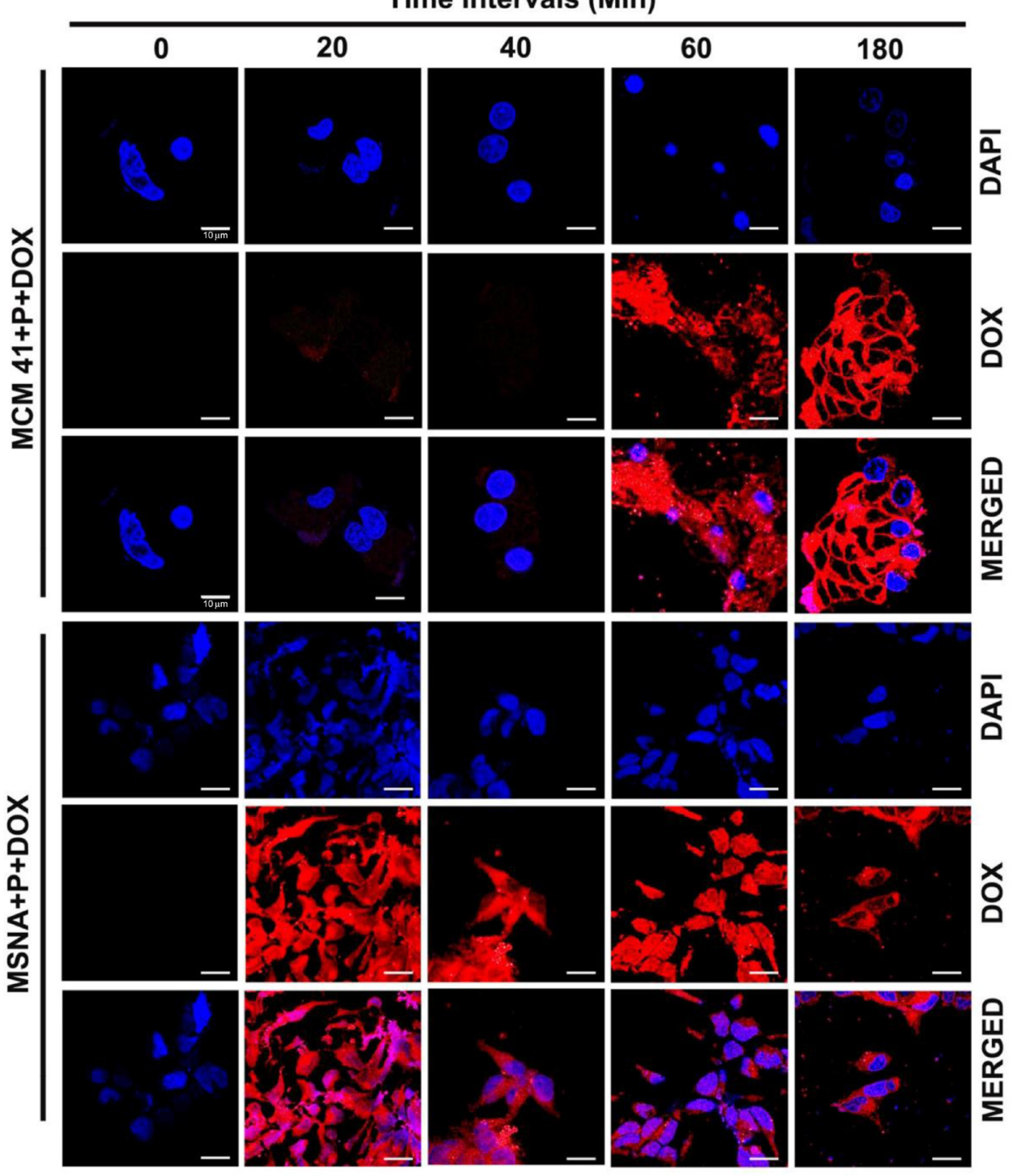

Figure 2: Toxicity and accumulation time of MCM-41P and MSNAP in MCF-7 cells. (A) Graph representing cell viability percentage of MCF-7 cells in presence of increasing concentration of MCM-41P from $500 \mathrm{ng} / \mathrm{mL}$ to $50 \mu \mathrm{g} / \mathrm{mL}$ for $24 \mathrm{~h}$. (B) Bar diagram representing MCF-7 viability on treatment with MSNAP from 20-100 $\mu \mathrm{g} / \mathrm{mL}$ for $24 \mathrm{~h}$. (C) Confocal images of MCF-7 cells with MCM$41 \mathrm{P}$ and MSNAP coated with DOX (red) with its corresponding DAPI (blue) staining at 0, 20, 40, 60, 180 min. and its corresponding images (DOX and DAPI) merged in MCF-7 cells. $n=3, p<0.05$ value was obtained in the treated groups compared to the control. ${ }^{* *}$ indicates $p$ value of less than or equal to 0.01 compared to control. ${ }^{*}$ indicates a $p$ value less than 0.05 . 
obtained at $180 \mathrm{~min}$. Whereas DOX-MSNAP uptake by MCF-7 cells was observed from $20 \mathrm{~min}$. and a maximum uptake was observed at $180 \mathrm{~min}$. These indicate that the rapid cellular accumulation of MSNAP in MCF-7 cells than MCM-41P [23].

\section{TEM based understanding of non-toxic nature exhibited by MSNAP}

Intracellular localization of MCM-41P and MSNAP was analyzed using a transmission electron microscope in MCF-7 cells. Cells treated with MCM-41P and MSNAP showed an increased cellular vacuolization compared to control cells (Figure 3A-3D). It was observed that a significant number of MCM-41P and MSNAP particles were localized in vacuoles (Figure 3F, 3G and 3J). MCM$41 \mathrm{P}$ primarily localized in mitochondria (Figure $3 \mathrm{H}$ ) and also in autophagosomes along with the degrading mitochondria (Figure 3F). Whereas MSNAP was not accumulated (Figure 3I-3K) in any organelle and it was mostly distributed in cytoplasm and cytoplasmic vesicles. Toxicity of MCM-41P was also confirmed by the formation of dilated ER in MCF-7 cells (Figure 3G), which was not observed in control cells. However, in MSNAP treated cells no autophagosomes were observed and MSNAP was mostly found in cytoplasm (Figure 3L) and also in cytoplasmic vesicles (Figure $3 \mathrm{~J}$ ).

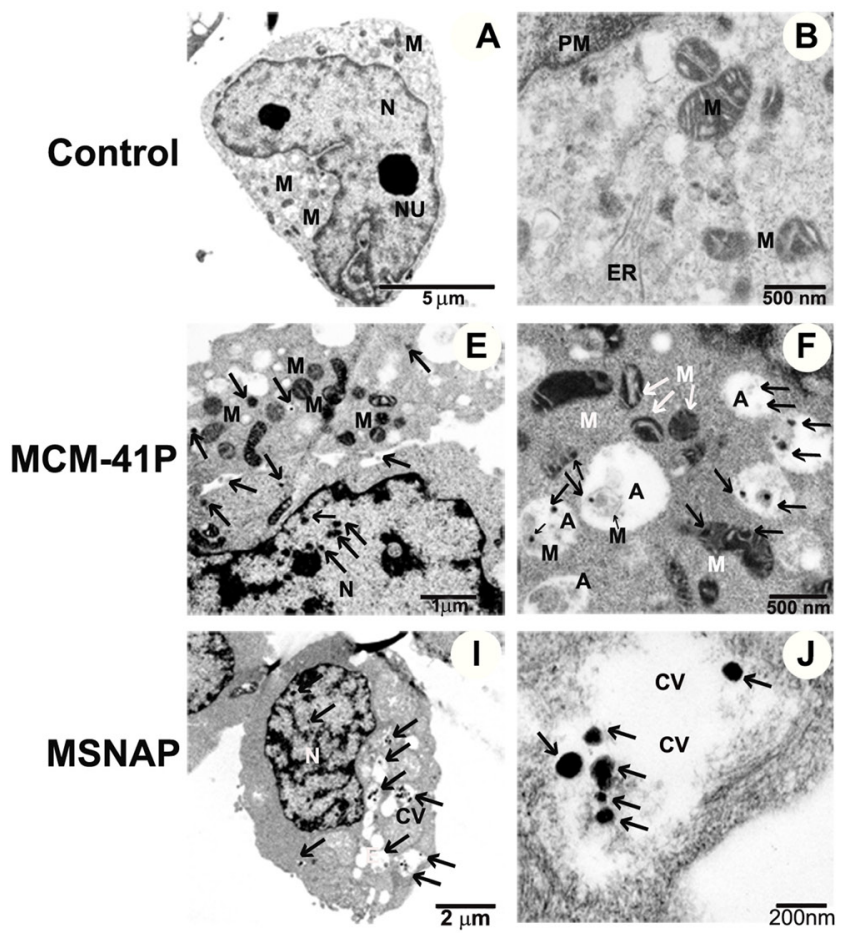

\section{MSNAP efficiently delivers curcumin to the MCF-7 cells resultantly induce apoptosis}

MSNAPs drug delivery capacity was assessed with CUR-MSNAP induced cell death. MCF-7 cells treated with CUR-MSNAP were subjected to viability assay and flow cytometry to analyze the percentage of cell death. Further to confirm MSNAP released curcumin inside the MCF-7 cells, intracellular curcumin concentration was determined using nanodrop.

$\mathrm{IC}_{50}$ concentration of unbound curcumin and CURMSNAP was determined using cell viability assay. Unbound curcumin-induced $50 \%$ cell death at $50 \mu \mathrm{M}$ concentration but CUR-MSNAP was able to induce the similar cell death at $30 \mu \mathrm{M}$ (loaded concentration) as shown in Figure 4A. Intracellular curcumin concentration was estimated using cellular extracts from cells treated with curcumin and CURMSNAP. The absorption of curcumin in the cellular extract was measured at $420 \mathrm{~nm}$ and which showed an effective concentration of $14 \mu \mathrm{M}$ (Figure 4B). Unbound curcumin induces cell death at $50 \mu \mathrm{M}$ while curcumin released by MSNAP achieves a similar cell death at a lower intracellular concentration. Similarly, analysis of cell death using propidium iodide followed by flow cytometric analysis showed that the cells treated with unbound curcumin had $34 \%$ cell death while CUR-MSNAP treated cells exhibited $48 \%$ cell death (Figure 4C).

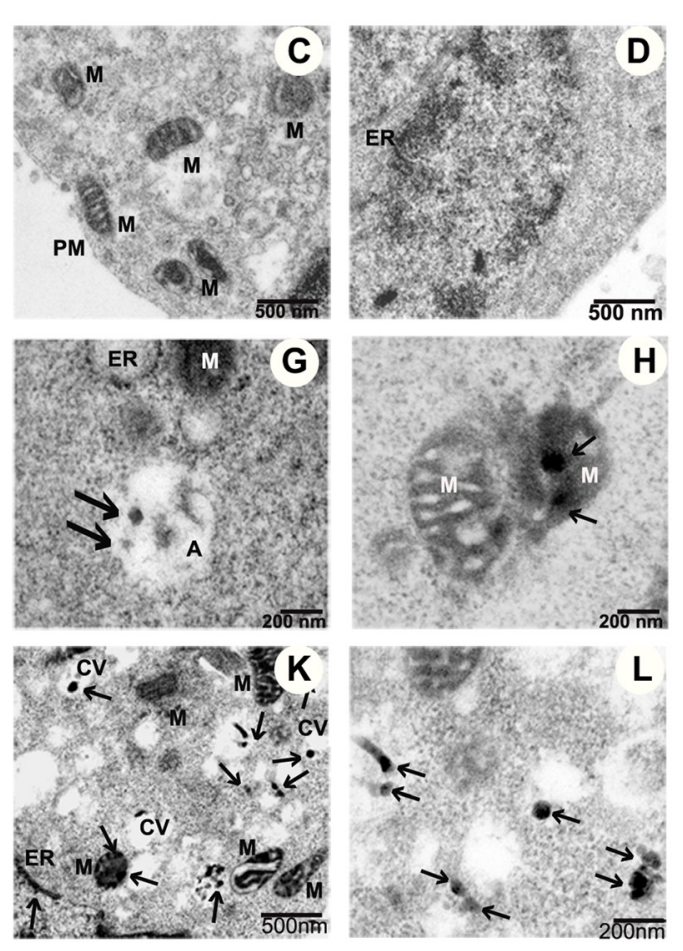

Figure 3: Subcellular localization of MCM-41 and MSNAP. (A-D) $5 \mu \mathrm{m}, 500 \mathrm{~nm}$ and $200 \mathrm{~nm}$ TEM images of control MCF-7 cells with nucleus $(\mathrm{N})$, endoplasmic reticulum (ER) mitochondria (M), Golgi $(\mathrm{G})$, plasma membrane (PM). Images of MCM-41P treated MCF-7 cells (E) $2 \mu \mathrm{m}$ image of cell, (F) $500 \mathrm{~nm}$ image indicating MCM-41P in autophagosome (A) (G) $200 \mathrm{~nm}$ image indicating MCM41P treated MCF-7 cells with bulged ER, $(\mathbf{H})$ MCM-41P localized in mitochondria. Images of MSNAP treated MCF-7 cell (I) whole cell, (J) MSNAP in cytoplasmic vesicles (CV) (K) $500 \mathrm{~nm}$ image of MSNAP localised in mitochondria and (L) $200 \mathrm{~nm}$ image with MSNAP present in cytoplasm. Black arrows indicate the presence of nanoparticle. 
Our viability assay and FACS data suggest that $30 \mu \mathrm{M}$ curcumin loaded on MSNAP (14 $\mu \mathrm{M}$ effective concentration) was able to induce a similar percentage of cell death as that of $50 \mu \mathrm{M}$ of unbound curcumin. Higher intracellular accumulation and sustained drug release from MSNAP induced cell death at lower curcumin concentration compared to extracellularly administered curcumin.

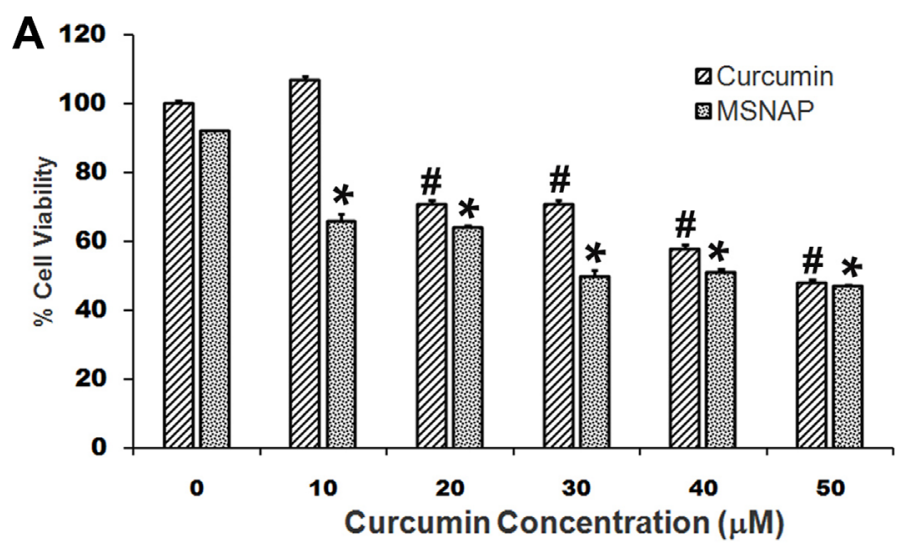

C

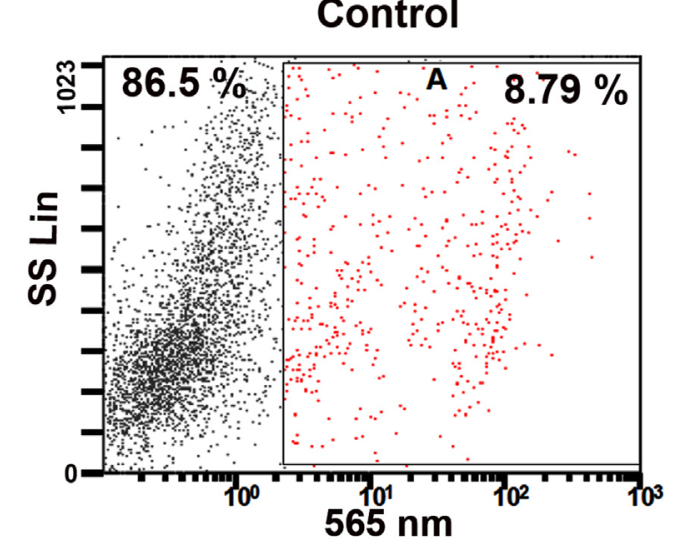

MSNAP

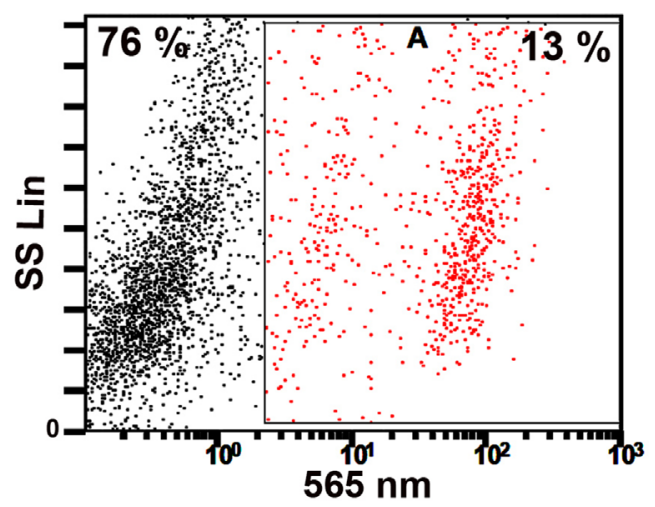

\section{CUR-MSNAP induce apoptosis by targeting mitochondria}

Further, in order to understand the mechanism of MSNAP released curcumin-mediated apoptosis, changes in activation of signalling proteins regulating apoptosis was studied in MCF-7 cells. We thus analyzed the change

B

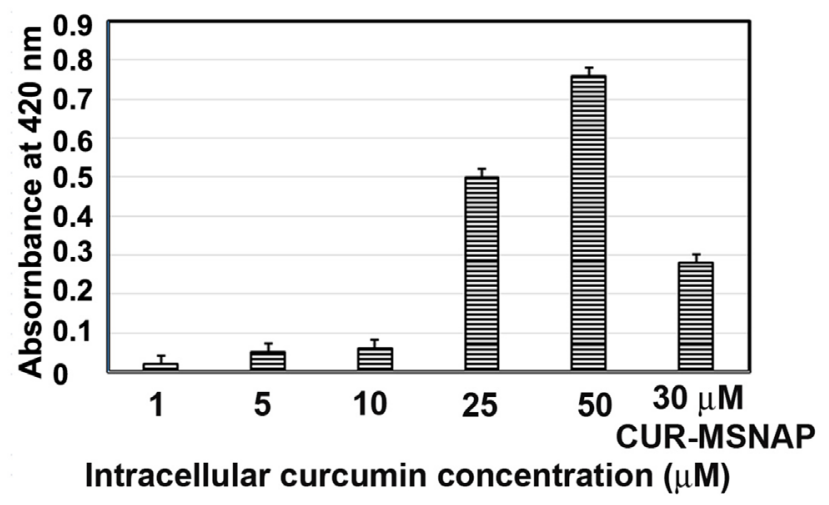

Curcumin

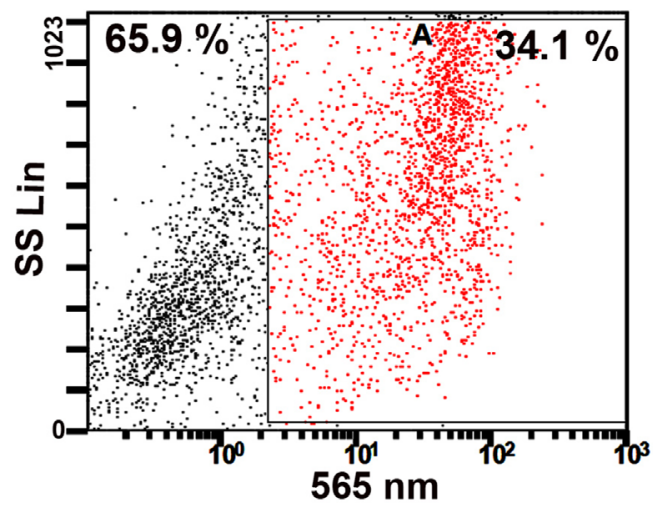

CUR-MSNAP

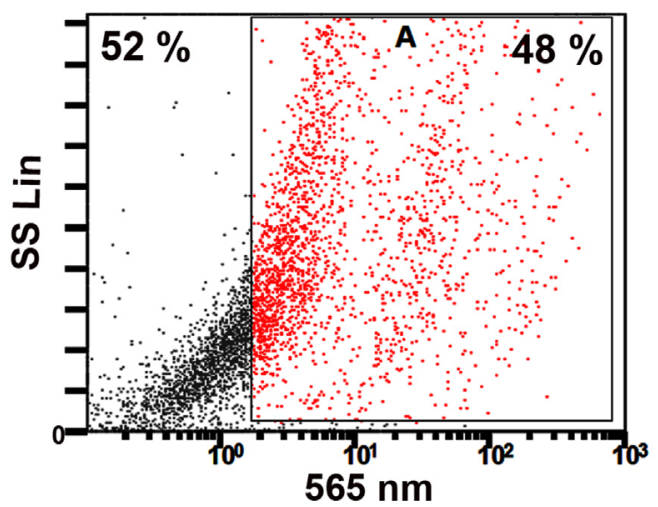

Figure 4: Effects of curcumin released from MSNAP. (A) Bar diagram of MCF-7 cells viability on treatment with 0-50 $\mu \mathrm{M}$ curcumin and MSNAP $(30 \mu \mathrm{g} / \mathrm{mL})$ loaded with $0-50 \mu \mathrm{M}$ of curcumin. (B) Graph indicating the intracellular curcumin concentration released from MSNAP at $72 \mathrm{~h}$. with standard curcumin. (C) FACS data of live and dead cell quantification of MCF-7 cells with curcumin, MSNAP and CUR-MSNAP. $n=3$, a significant $p$ value of 0.05 was obtained comparing control and treated samples. *indicates $P \leq 0.05$ significance of CUR-MSNAP compared to their respective control. \#indicates $P \leq 0.05$ significance of curcumin treated cells compared to the untreated control. 
in expression of the protein which is involved in ER homeostasis, apoptosis and cell survival on curcumin, and CUR-MSNAP treatment.

CUR-MSNAP and unbound curcumin increased the expression of CHOP, cleaved PARP, caspase 9, cleaved caspase 9, caspase 12, calnexin and PTEN (as shown in Figure 5B-5C). Additionally, expression of pAkt, IRE1 $\alpha$, PERK, and GRP 78 proteins were markedly downregulated on treatment with curcumin and CURMSNAP (Figure 5A-5B). Calnexin, an ER protein, expression was upregulated to two folds of curcumin and CUR-MSNAP treatment (Figure 5B).

Unbound curcumin and CUR-MSNAP downregulated Akt phosphorylation at Ser 473 however total Akt level was not altered on their treatment. Treatment of cells with curcumin and CUR-MSNAP enhanced phospho PTEN (ser 380) expression by 1.75 fold compared to the untreated cells (Figure 5B). Immunoblot study with the cleaved PARP (C-PARP) and caspase 12 showed no significant variation in their expression upon treatment with unbound-curcumin and untreated cells (Figure 5C). However, C-PARP and caspase 12 expressions were increased two folds upon CUR-MSNAP treatment as compared to the control (Figure 5C). Caspase 9 and cleaved caspase 9 expressions were also elevated on CURMSNAP treatment and a fourfold increase in expression of cleaved caspase 9 was observed. Unbound curcumin and CUR-MSNAP treatment elevated expression of CHOP to 1.5 fold and 1.3 fold respectively compared to the control cells. But no significant changes in caspase 6 and c-caspase 6 was observed in MCF-7 cells treated with CUR-MSNAP, when compared to the control cells.

Further CUR-MSNAPs induction of apoptosis was studied by understanding the ultrastructural changes of MCF-7 cells. The MCF-7 cells were treated with $30 \mu \mathrm{M}$ curcumin loaded MSNAP for $24 \mathrm{~h}$ and $48 \mathrm{~h}$. Bio-TEM images of these samples indicated that CUR-MSNAP treated cells at $24 \mathrm{~h}$ and $48 \mathrm{~h}$ had distinct morphological changes observed in mitochondria and nucleus as compared to cells with MSNAP alone and control cells. MSNAP (Figure 3L) localizes primarily in the cytoplasm whereas curcumin loaded MSNAPs are mostly distributed in nucleus and mitochondria. CUR- MSNAP treated cells at $24 \mathrm{~h}$ (Figure 6C, 6D) showed swollen mitochondria with cristae and disrupted nuclear membrane. Additionally, cells treated with CUR-MSNAP at 48 h (Figure 6G, 6H) showed cells with swollen mitochondria, damaged plasma membrane and apoptotic bodies. Figure 6C, suggest that CUR-MSNAP treated cells at $24 \mathrm{~h}$ exhibit swollen mitochondria with the vesicular inner membrane. However, $48 \mathrm{~h}$ after incubation (Figure 6G) lost vesicular inner membrane and a swollen outer mitochondrial membrane was observed.

\section{DOX-MSNAP inducing cell death in MCF-7R cells}

The ability of MSNAP in delivering drug to resistant cell lines was studied in DOX-resistant breast cancer cell lines. MCF-7R cells treated with MSNA-DOX-induced cell death at a lesser concentration of DOX compared to free DOX.

Viability assay indicates that (Figure 7B) $\mathrm{IC}_{50}$ concentration of unbound DOX was $250 \mu \mathrm{g} / \mathrm{mL}$ found in resistant cells whereas DOX-MSNAP induced the same effect at $150 \mu \mathrm{g} / \mathrm{mL}$ (Figure 7D). However, there were no significant differences observed in unbound curcumin and CUR-MSNAP in their inhibitory concentration. $\mathrm{IC}_{50}$ of CURMSNAP and free curcumin in MCF-7R was $75 \mu \mathrm{M}$ (Figure 7A-7C). The similar effect in cell death was observed in flow cytometric analysis. However, when MSNAP co-loaded with curcumin and doxorubicin (CUR-DOX-MSNAP), an increased percentage of cell death were observed (Figure
A

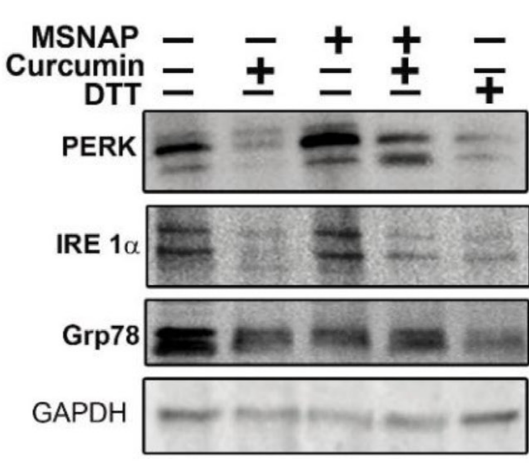

B

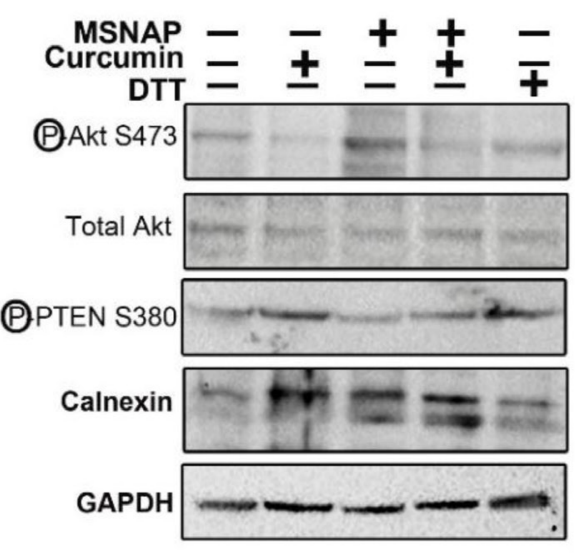

C

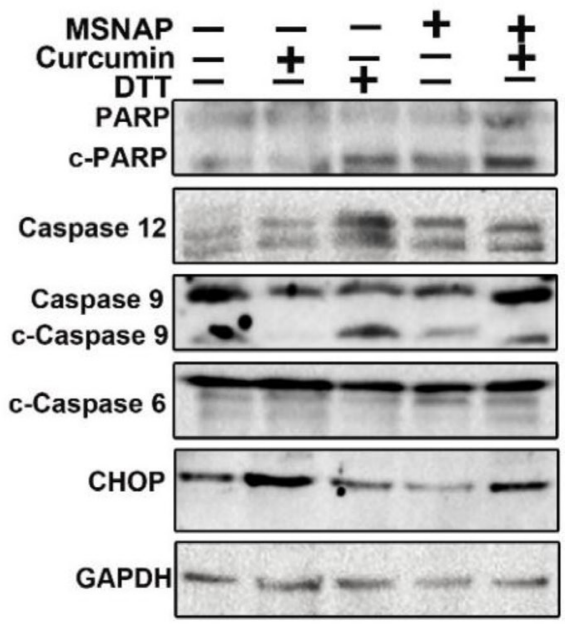

Figure 5: Signalling induced by intracellular released curcumin from MSNAP. (A) Images of blot probed for PERK, IRE1 $\alpha$, GRP78 (B) Panel indicating western blots of pAkt, TAkt, PTEN and calnexin (C) Blots of proteins involved in apoptosis. 
Table 1: Parameters of curcumin docking with proteins

\begin{tabular}{llllllll}
\hline & Caspase 3 & IRE 1 $\alpha$ & PARP & PERK & PTEN & Caspase 9 & Akt1 \\
\hline Binding energy & -4.86 & -6.99 & -4.92 & -4.39 & -6.59 & -4.16 & -4.84 \\
Ligand efficacy & -0.18 & -0.26 & -0.18 & -0.16 & -0.24 & -0.15 & -0.18 \\
Inhibitory constant & $275.8 \mu \mathrm{M}$ & $7.53 \mu \mathrm{M}$ & $245.58 \mu \mathrm{M}$ & $609.67 \mu \mathrm{M}$ & $14.8 \mu \mathrm{M}$ & $894.81 \mu \mathrm{M}$ & $282.16 \mu \mathrm{M}$ \\
Intermolecular energy & -6.98 & -8.64 & -6.84 & -5.68 & -8.51 & -5.68 & -6.55 \\
Vdw_desol_energy & -6.74 & -8.42 & -6.48 & -5.31 & -8.12 & -5.52 & -6.23 \\
Electrostatic energy & -0.62 & -0.22 & -0.83 & -0.37 & -0.39 & -0.16 & -0.31 \\
No. of H bonds & 2 & 1 & 3 & 2 & 4 & 1 & 3 \\
\hline
\end{tabular}

$7 \mathrm{G})$. Flowcytometric data indicates that DOX-MSNAP at $150 \mu \mathrm{g} / \mathrm{mL}$ induces $49 \%$ (Figure 7E) of cell death and CURMSNAP induces $25 \%$ cell death in MCF-7R cells. CUR $(75 \mu \mathrm{M})$-DOX $(150 \mu \mathrm{g} / \mathrm{mL})$-MSNAP showed enhanced $82 \%$ of cell death (Figure 7E). Enhanced cell death of 78\% was observed at half the $\mathrm{IC}_{50}$ concentration of CUR (37.5 $\mu \mathrm{M})$ and DOX $(75 \mu \mathrm{g} / \mathrm{mL})$ loaded on MSNAP (Figure 7E) in MCF-7R cells. Similar percentage of cell death was also obtained with viability assay in MCF-7R cells (Figure $7 \mathrm{G}$ ) with CUR-DOX-MSNAP. $\mathrm{IC}_{50}$ (curcumin $50 \mu \mathrm{M}$ and Doxorubicin $150 \mu \mathrm{g} / \mathrm{mL}$ ) concentration of curcumin and doxorubicin loaded on MSNAP induced $80 \%$ of cell death and at sub-IC $\mathrm{I}_{50}$ concentrations (Cur $25 \mu \mathrm{M}$ and DOX $75 \mu \mathrm{g} /$ $\mathrm{mL}$ ), induced $78 \%$ of cell death. $\mathrm{IC}_{50}$ of DOX against MCF-7 cells was $100 \mu \mathrm{g} / \mathrm{mL}$ (data not shown), whereas $\mathrm{IC}_{50}$ of DOX against MCF-7R was $250 \mu \mathrm{g} / \mathrm{mL}$. But DOX loaded MSNAP induced $50 \%$ of cell death at concentration of $150 \mu \mathrm{g} / \mathrm{mL}$ in MCF-7R. However, at the same concentration of DOXMSNAP $(150 \mu \mathrm{g} / \mathrm{mL})$ induced nearly $80 \%$ of cell death in sensitive MCF-7 cells.

\section{Curcumin docking studies}

Curcumin docking with apoptosis associated proteins was tabulated (Table 1).

Curcumin interacts with caspase-3 (Figure 8) by forming 2 hydrogen bonds between curcumin phenolic ring and tyrosine 195 and also with glycine 125 . Additionally $\mathrm{C}=\mathrm{O}$ group of curcumin interaction with arginine 164 through pi-pi bonding. IRE $1 \alpha$ binds with curcumin through a hydrogen bond with asparagine 244. Other than H-bonding, histidine 242 of the protein interacts with curcumin phenolic ring.

Curcumin forms 3 hydrogen bonds with PARP's lysine 282, two hydrogen bonds were formed from phenolic ring with histidine 285 and glycine 335 . Curcumin bends to interact (Figure 8) with PARP to form a stable confirmation with binding energy -4.92 . Curcumin binds with PERK by forming two hydrogen bonds with glycine 985 and lysine 938. Curcumin interacts with PTEN with the least binding energy -6.59 ,
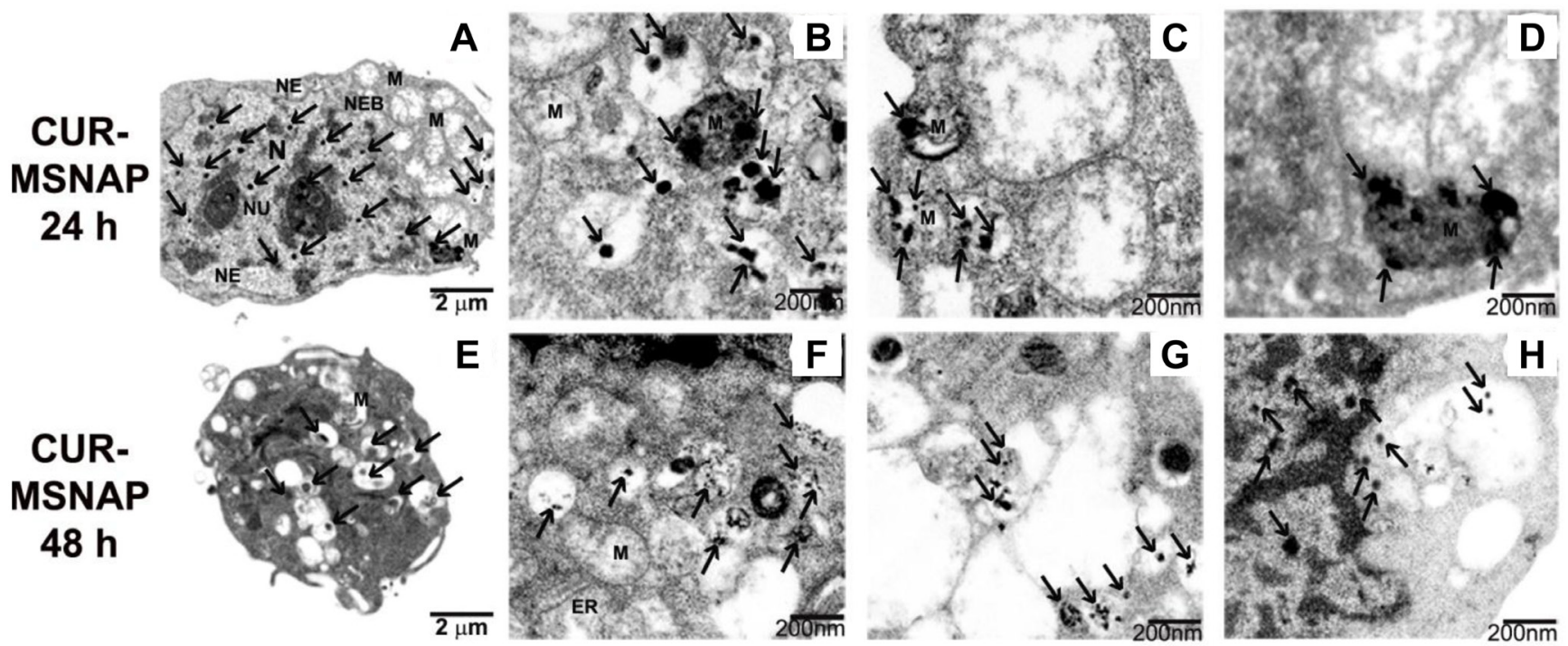

Figure 6: Apoptosis induced by CUR-MSNAP. TEM images indicating MCF-7 cells treated with CUR-MSNAP for 24 h. (A) whole cell with (N) nucleus, (Nu) Nucleolus, (MS) Swollen Mitochondria, (NE) Nuclear envelop, black arrows indicating MSNAP, (B-D) $200 \mathrm{~nm}$ TEM image with swollen mitochondria. TEM images of CUR-MSNAP treated MCF-7 cells for 48 h. (E) whole cell, (F), (G) $200 \mathrm{~nm}$ scale image with fully swollen mitochondria (H) $200 \mathrm{~nm}$ scale image with disrupted nuclear membrane. Black arrows indicate CUR-MSNAP. 
4 hydrogen bond, phenolic ring from curcumin forms bond with alanine 126, arginine 130, histidine 272 and $\mathrm{C}=\mathrm{O}$ group interacts with lysine 330 with a slight bend confirmation.

Curcumin interacts with Aktl through 3 hydrogen bond formation with arginine 25, arginine 86 and asparagine 86 with a slight bend confirmation. Curcumin interacts with caspase 9 through two hydrogen bond with arginine 177, and glycine 240 .

\section{DISCUSSION}

Exploration of new nanoparticles for better efficiency and reduced toxicity resulted in the development of non-spherical MSNAP. Synthesis of MSNs is usually achieved by two methods (a) simultaneous grafting of surfactant micelles along with silica precursor, and (b) the silica precursor is allowed to accumulate over the pre-formed surfactant micelle
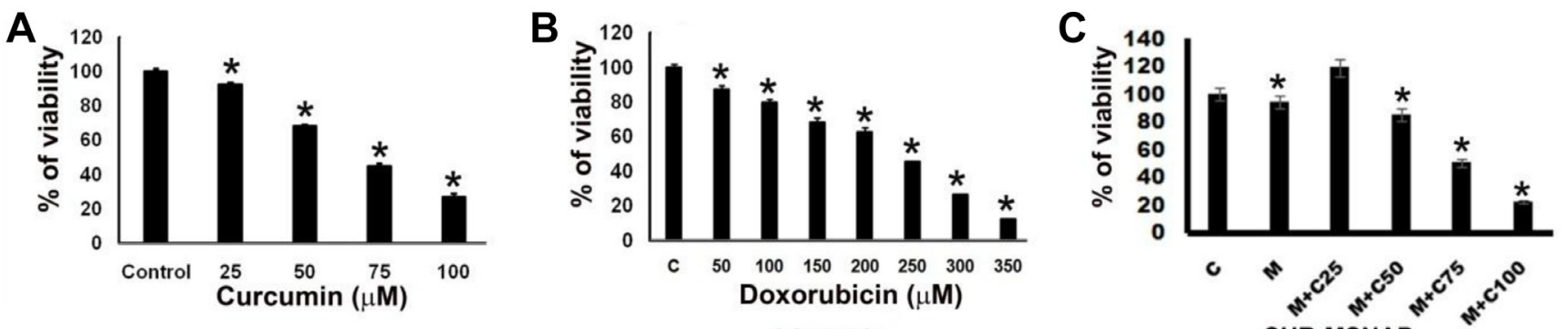

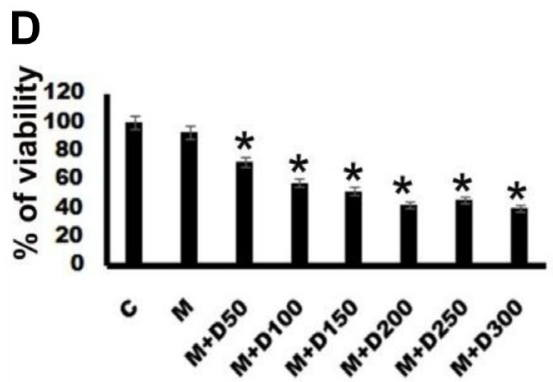

$\mathbf{E}$

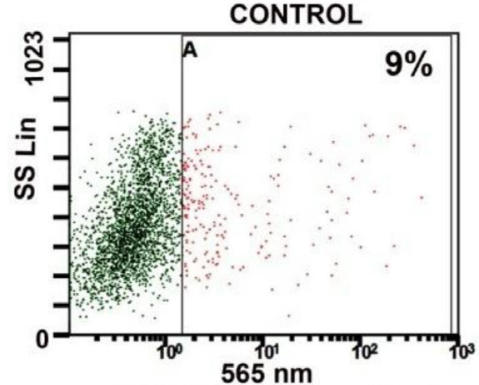

$\mathbf{F}$
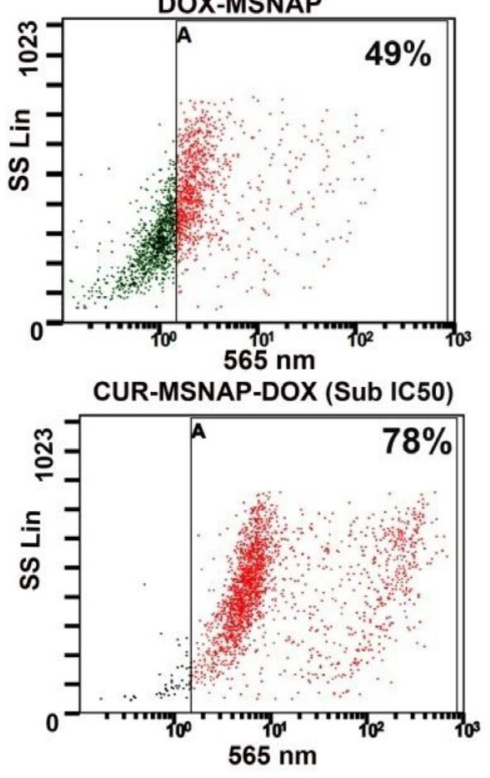

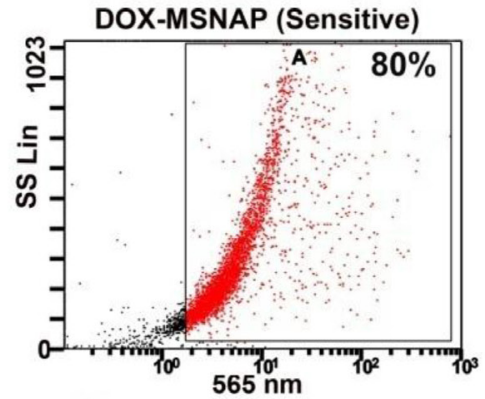

G

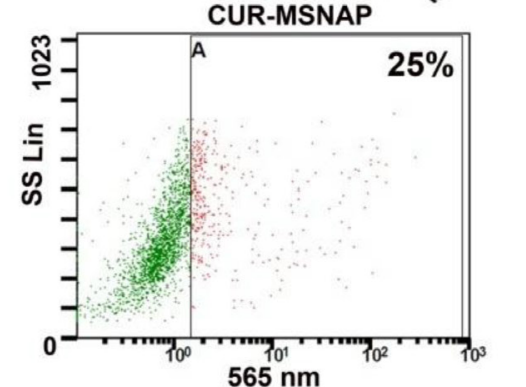

CUR-MSNAP-DOX (IC50)

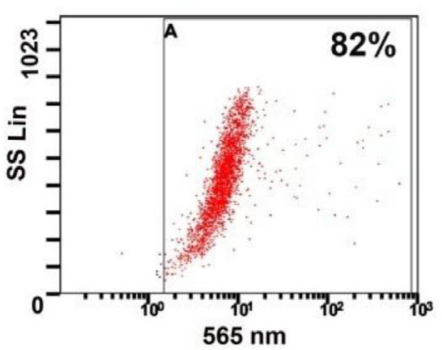

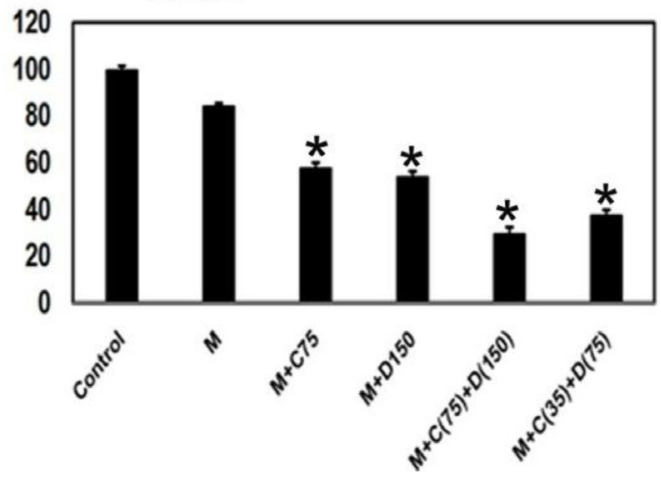

Figure 7: Effect of CUR and DOX loaded MSNAP on MCF-7R. Graph of viability assay result with different concentrations of (A) CUR (B) DOX (C) CUR-MSNAP (M+C) (D) DOX-MSNAP (M+D) against MCF-7R. (E) FACS data with SSC vs FL3 revealing cell death percentage of Control, CUR-MSNAP (M+C), DOX-MSNAP (M+D), CUR (75 $\mu \mathrm{M})$-DOX (150 $\mu \mathrm{g} / \mathrm{mL})$-MSNAP (M+C+D), CUR $(35 \mu \mathrm{M})$-DOX $(75 \mu \mathrm{g} / \mathrm{mL}),(\mathbf{F})$ FACS data representing MSNA-DOX $(150 \mu \mathrm{g} / \mathrm{mL})$ induced percentage of cell death in MCF-7 sensitive cells $(\mathbf{G})$ representative graph with viability assay data in MCF-7R. $n=3$, *indicates significance of $P<0.05$ compared to their respective control. 
$[24,25]$. MCM-41 was synthesized by former method [26] whereas MSNA was prepared by the latter method in midst of acid hydrolysis and condensation. Structural analysis of MSNAP with SEM revealed they were mostly in discoid shaped. Though discoid shaped is the predominant form, very few gyroids were also observed [27]. Reducing the micelle formation time and PEI coating on MSNA resulted in a non-spherical shape and smaller sized particles compared to the earlier report $[5,27]$. Drug loading studies reveal MSNAP binds to curcumin $80 \%$ more than MSNA. Multivalent amino groups of $\mathrm{PEI}$ adsorbs the $\mathrm{C}=\mathrm{O}$ and $-\mathrm{OH}$ groups of curcumin electrostatically, [28] which accounts for MSNAP higher drug loading. PEI coating not only enhances the efficient transfection to cells [29] but also enhances drug adsorption on the nanoparticle [30].

Curcumin release studies indicated that MSNAP released curcumin in a sustained manner, CUR-MSNAP has enhanced drug releasing capacity as compared with CUR-MCM-41P. As bigger pore sized nanostructures release drug efficiently [31], MSNAP released curcumin better due to its bigger pore size compared to MCM-41P [23]. Electrostatic interactions between the functional groups of curcumin and PEI form a zwitterionic complex. This complex is converted to protonated amines and free isomer of curcumin in water or buffer at neutral $\mathrm{pH}$ [31]. The gradual PEI protonation is directly proportional to the amount of drug released from PEI coated MSN. Acidic
$\mathrm{pH}$ aided higher percentage of protonation (45\%) than the neutral $\mathrm{pH}(20 \%)$ [32]. Our drug release studies data from MCM-41P showed $58 \mathrm{nM}$ curcumin was released at $\mathrm{pH}$ 7.4 at $72 \mathrm{~h}$. indicating the sustained release [33]. Thus, neutral $\mathrm{pH}$ played a vital role in the sustained release of curcumin from CUR-MSNAP.

Interaction of MSNAP with MCF-7 cells suggests its non-toxic nature. MCM-41P (Figure 2A) was nontoxic till $500 \mathrm{ng} / \mathrm{mL}$ and MSNAP was non-toxic till $20 \mu \mathrm{g} /$ $\mathrm{mL}$ (Figure 2B). Toxicity was proved by ultra-structural changes in MCM-41P challenged cells (Figure 3F, 3G $-3 \mathrm{H})$. Autophagy is the cellular process to eliminate the toxins and pathogens from the mammalian cells [34]. Earlier reports with silica particles have also indicated the formation of auto-phagosome in MRC-5 cells [35]. Previous reports states in cancer cells, nanoparticles were taken up through plasma membrane and were accumulated either in mitochondria or in lysosomes. These stable solid particles cause leakage of lysosomal and mitochondrial membrane leading to cell death. The possibility of MCF-7 cells undergoing autophagocytosis could be attributed to the toxic nature of MCM-41P [36]. Whereas, MSNAP's interaction with MCF-7 cells was non-toxic as most of the nanoparticles accumulate in cytoplasmic vesicles (Figure 3J).Nanoparticles with different shapes has different contact angle with plasma membrane. This variation in contact angle leads to the difference in particle uptake and its localisation. Non-
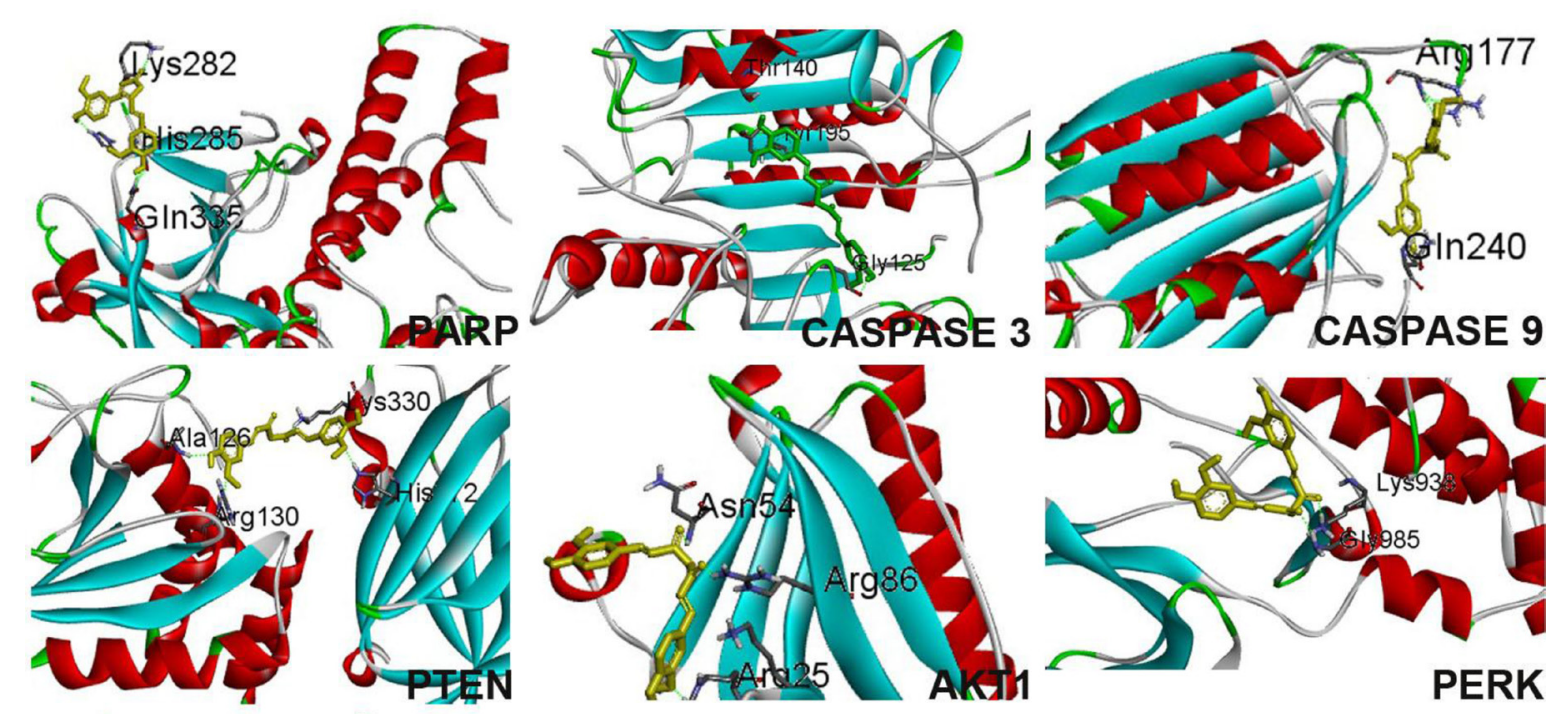

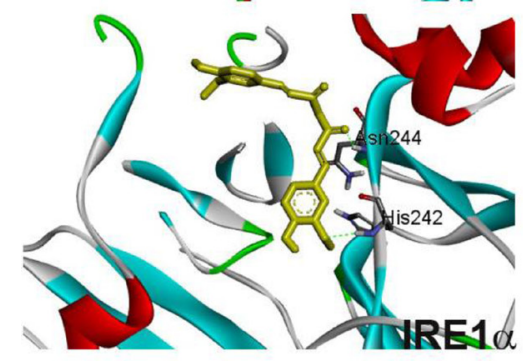

Figure 8: Curcumin binding confirmation with proteins PARP, caspase 3, caspase 9, PTEN, Akt1, PERK, IRE1 $\alpha$. 
spherical MSNAP might have generated different contact angle with MCF-7 cell membrane which could accounted for its localisation in cytoplasmic vesicle and its nontoxic nature [37].

CUR-MSNAP mechanism of inducing apoptosis was further studied in MCF-7 cells. Curcumin has been reported to induce apoptosis by modulating proteins of ER and mitochondria in numerous cancer cells [38-40]. GRP78 the HSP chaperone is the main stress sensor of ER which controls the activity of PERK, IRE1 $\alpha$, and ATF6. PERK, ATF6, and IRE1 $\alpha$ dissociate from GRP 78 under stress condition and activate the downstream signalling molecules to restore the ER homeostasis [41]. Our western blot results (Figure 5A) with downregulation of PERK, IRE $1 \alpha$ and GRP 78 by unbound curcumin and CUR-MSNAP indicate an altered ER homeostasis. Reports indicate that phosphorylation of Akt at ser473 enhances the cell survival whereas an increase in PTEN phosphorylation at ser 380 activity decreases the cell survival [42]. Our data (Figure 5B) thus suggested that unbound curcumin and CUR-MSNAP may regulate the cell survival by modulating the phosphorylation status of Akt and PTEN in MCF-7 cells. Caspases are the link between regulations of cell death and inflammation [43]. Proteolytic cleavage of caspases amplifies the signal to induce apoptosis [44]. Caspase 12 aid in cleaving procaspase 9 which is cascadically cleaves caspase 3 [45]. Our result suggested that (Figure 5C) unbound curcumin and CUR-MSNAP apoptosis activation may be implemented through caspase 12, caspase 9 and PARP. Cleaved caspase 9 was activated more than four folds compared to free curcumin administered cells. This proves that CUR-MSNAP induced better apoptosis than free curcumin. Our result was in consistent with the previous report where poly (ethylene glycol) methyl etherb-(poly lactic acid-co-poly (b-amino esters)) of paclitaxelinduced better apoptosis in leukemic K562 cells than free paclitaxel [46].

Apoptosis mediated through mitochondria induces alteration in the inner mitochondrial membrane convoyed with cisternae degradation. Vesicular structure of the mitochondrial inner membrane was altered which eventually leads to the loss of cisternae [47-50]. Ultrastructural images (Figure 6) suggest that CURMSNAP influenced cells to undergo apoptosis by remodelling the inner mitochondrial membrane from normal vesicular structure to swollen vesicular at $24 \mathrm{~h}$ and completely swollen mitochondria at $48 \mathrm{~h}$. Interestingly, it has been reported that unbound curcumin induces apoptosis by damaging chromosome and the plasma membrane in MCF-7 cells, however, there is no report to suggest that unbound curcumin cause mitochondrial insult [51]. Lv et al. reported free curcumin-induced apoptosis in breast cancer cells by mitochondrial insult with cisternae degradation at $48 \mathrm{~h}$ [52]. Our TEM result (Figure 6C-6D) signifies that CUR-MSNAP induced the similar effect at
$24 \mathrm{~h}$. This further emphasizes the advantage of MSNAP in curcumin delivery to cancer cells. The faster intracellular accumulation of the MSNAP could have contributed to earlier cisternae degradation by CUR-MSNAP than the free curcumin. Caspases are involved in mitochondriamediated apoptosis [53, 54]. CUR-MSNAP treatment resulted in mitochondrial disruption might be the cause for increased expression of cleaved caspase 9 and caspase 12 as compared to unbound curcumin treatment.

In MCF-7R cells, though curcumin (Figure 7E, $7 \mathrm{~F}, 7 \mathrm{G}$ ) alone did not significantly affect the cell death, curcumin in combination with DOX loading on MSNAP, enhanced the percentage of cell death. Similar to other previous reports, nano delivery of DOX induces $50 \%$ of cell death at a lower concentration of drug than the native drug [55]. Our results with the effect of MSNAP loaded curcumin and doxorubicin on MCF-7 and MCF-7R suggest, MCF$7 \mathrm{R}$ could be sensitised by nanodrug. Further, resistance in MCF-7R was confirmed by its sensitisation to DOX. $\mathrm{IC}_{50}$ of DOX in MCF-7R was obtained at $250 \mu \mathrm{g} / \mathrm{mL}$ (Figure 7B) whereas in sensitive MCF-7 cells, $\mathrm{IC}_{50}$ concentration of DOX was $100 \mu \mathrm{g} / \mathrm{mL}$ (data not shown). Additionally, DOX resistance was also cross checked with DOXMSNAP in MCF-7 cells. The $\mathrm{IC}_{50}$ concentration of DOX in MCF-7R (DOX-MSNAP $150 \mu \mathrm{g} / \mathrm{mL}$ ) was challenged in sensitive cells which yielded in nearly $80 \%$ of cell death (Figure 7F). Drug resistance in cancer cells could be due to increased drug metabolism, drug efflux, drug inactivation or modification of drug targets [56]. Nanocarrier shaves the ability to accumulate in tumour tissue either passively or actively [57]. As most of the nanocarriers were taken up through endocytosis mediated pathway which can be bypass the drug efflux mechanism [58]. In DOX resistant uterine sarcoma tumour cell line MES-SA/Dx-5, liposome coated copper MSN with DOX induce apoptosis at a lower concentration compared to the pure drug [59]. Similarly, our preliminary finding suggests that CUR-DOX-MSNAP induced cell death in MCF-7R cells with lesser drug concentration.

\section{MATERIALS AND METHODS}

\section{Synthesis of non-spherical nanoparticle}

'Origami' method was adopted for the synthesis of non-spherical MSN (MSNA) with slight modification [27]. In brief, $\mathrm{H}_{2} \mathrm{O}, \mathrm{HCl}$, formamide, CTAB (Cetyltrimethylammonium bromide) were mixed in a molar ratio of 100:7.8:10.2:0.11 and magnetically stirred at $600 \mathrm{rpm}$ for $40 \mathrm{~h}$. at room temperature. Silica formation was initiated by adding $0.3 \mathrm{~mL}$ TEOS drop wise to this mixture and incubated further for $18 \mathrm{~h}$. The template was removed by refluxing in $\mathrm{HCl}$ and methanol (1:20) overnight. The obtained nanostructures were coated with $0.3 \%$ of $10 \mathrm{kDa}$ PEI (Alfa Aesar) [5]. MCM-41 was synthesized and coated with PEI as described earlier [33]. 


\section{Characterization of MSNAP}

Structural analysis of MSNAP was carried out with TEM and SEM. MSNAP was dried on carbon paper for SEM (Evo18 Zeiss Munich, Germany), which executes at $20 \mathrm{KV}$ and with Energy Dispersive X-ray (EDX) (Bruker, Madison, WI, USA). MSNAP was dried on carbon grids for High-resolution transmission electron microscope (HRTEM, T12 tecnai, Hillsboro, Oregon USA) HT650 ES1000W t $120 \mathrm{kV}$. The pore size of these nanoparticles was measured by image $\mathrm{J}$ software of HRTEM.

\section{Drug loading and release studies}

$10 \mathrm{mg}$ of synthesized MSNAP was suspended separately in $5 \mathrm{mM}$ curcumin (Alfa Aesar) in ethanol for $24 \mathrm{~h}$. in an orbital shaker. The unbound free curcumin was removed after $24 \mathrm{~h}$. and its absorbance at $420 \mathrm{~nm}$ was compared with $0 \mathrm{~h}$. in nanodrop (Biospec Nano, Shimadzu). Percentage of curcumin loaded in both nanostructure was determined by the formula (Abs at $0 \mathrm{~h}$ - Abs at $24 \mathrm{~h} / \mathrm{Abs}$ at $0 \mathrm{~h}$ )*100.

The concentration of curcumin released from CURMSNAP ( $30 \mu \mathrm{M}$ curcumin loaded with $30 \mathrm{mg} / \mathrm{mL}$ MSNAP) as determined in phosphate buffer saline (PBS) at pH 7.4. Initially, $4 \mathrm{mg} / \mathrm{mL}$ of both the MSN loaded with curcumin was immersed in PBS separately till $96 \mathrm{~h}$ Curcumin released in PBS was analyzed at every $12 \mathrm{~h}$ at $420 \mathrm{~nm}$ in nanodrop. The concentration of curcumin released was calculated by referring to the standard curcumin graph.

\section{Cell culture}

Breast adenocarcinoma (MCF-7) cells were cultured in IMDM (Gibco/Life Technologies, Gaithersburg, MD, USA) medium with $10 \%$ FBS (Gibco BRL) in $5 \% \mathrm{CO}_{2}$ incubator at $37^{\circ} \mathrm{C}$. Serum-free media was used in all the experiments involved with nanoparticle.

\section{Development of doxorubicin resistant MCF-7 cells (MCF-7R)}

Doxorubicin (DOX) (Doxotero, Hetero HC, Hyderabad, India) resistant cells were developed by adapting the MCF-7 cells to increasing concentration of doxorubicin from $500 \mathrm{ng} / \mathrm{mL}$ to $33 \mu \mathrm{g} / \mathrm{mL}$ [60] (Clinically relevant resistant DOX concentration in patient's plasma). Initially, MCF-7 cells were exposed to $500 \mathrm{nM}$ of DOX for $48 \mathrm{~h}$. and retrieved in fresh media until the plate reached confluence. The same procedure was repeated with the higher concentrations from $1 \mu \mathrm{M}$ to $33 \mu \mathrm{M}$.

\section{Toxicity assays}

\section{Viability assay}

Cell death induced by MSN, was assessed with water-soluble tetrazolium-1 (WST-1) reagent (Roche,
Germany $\mathrm{GmbH})$. Briefly, 10,000 cells were seeded in 96 well plate (Greiner, Bio-One, Ireland) and allowed to adhere overnight. MSNAP and MCM-41P of concentration from $0.5 \mu \mathrm{g} / \mathrm{mL}$ to $100 \mu \mathrm{g} / \mathrm{mL}$ were added to the plate in triplicates and incubated for $24 \mathrm{~h}$. followed by addition of $5 \mu \mathrm{L}$ WST-1. The plate was read at $450 \mathrm{~nm}$ in a microplate reader (Biotek, Model FLx800, Vermont, USA). Percentage of live cells was calculated from formula (OD of sample/OD of control) X100.

\section{Accumulation of MSNs in MCF-7 cells}

Accumulation of nanoparticles in MCF-7 cells was analyzed by confocal laser scanning microscopy (CLSM), (LSM 500, Zeiss, Munich, Germany). Cells were grown on coverslips till they attain $60 \%$ confluence. $5 \mathrm{nM}$ DOX (Doxotero, Hetero HC, Hyderabad, India) loaded silica nanostructures (DOX-MSNAP) were incubated with MCF-7 cells for different time intervals such as $0,20,40$, 60,120 and $180 \mathrm{~min}$. Then the coverslips were fixed with $4 \%$ paraformaldehyde followed by DAPI staining. Cells were imaged with CLSM with excitation at $405 \mathrm{~nm}$ and emission from 580 to $620 \mathrm{~nm}$ [33].

\section{Bio-TEM studies for subcellular localization of MSNs in MCF-7 cells}

The non-toxic concentrations of MCM-41P and MSNAP were incubated for $72 \mathrm{~h}$. and $30 \mu \mathrm{M}$ of CURMSNAP was incubated for 24 and $48 \mathrm{~h}$. in MCF-7 cells. After incubation cells were harvested and fixed in a fixative mixture of $2.5 \%$ glutaraldehyde, $2 \%$ sucrose and complete media for $12 \mathrm{~h}$. Then the fixed cells were stained with $1 \%$ osmium tetroxide. Followed by dehydration in a series of ethanol from $70 \%-100 \%$. The fixed cells were added with $100 \%$ propylene oxide then gradually transferred to $100 \%$ epoxy resin (TAAB, England) by decreasing the percentage of propylene oxide. Finally, cells were kept in pure resin for $5 \mathrm{~h}$. and embedded in a freshly prepared resin at $50^{\circ} \mathrm{C}$ for $48 \mathrm{~h}$. Resin embedded samples were made to $80-100 \mathrm{~nm}$ thin sections with ultra-microtome. These sections were counterstained with uranyl acetate and lead citrate and imaged with transmission electron microscope (Tecnai $\mathrm{G}^{2}$, Hillsboro, Oregon, USA) at $80 \mathrm{KV}$.

\section{Evaluation of CUR-MSNAP induced apoptosis in MCF-7 cells}

\section{Viability assay}

$\mathrm{IC}_{50}$ value of CUR-MSNAP in MCF-7 cells was determined by WST-1 assay as mentioned earlier. Cells were treated with different concentration of curcumin $(5-50 \mu \mathrm{M})$ loaded on non-toxic concentrations of $30 \mu \mathrm{g} /$ mL MSNAP. After $72 \mathrm{~h}$, cell viability was measured with 
WST-1 reagent as described earlier [33]. Percentage of live cells was determined by the formula (Absorbance of treated cells / Absorbance of control cells)*100.

FACS analysis was used to quantify live and dead cells on curcumin, MSNAP, CUR-MSNAP treatment. Cells were grown in 12 well plate (Greiner) and treated independently with $30 \mu \mathrm{g} / \mathrm{mL}$ MSNAP, $50 \mu \mathrm{M}$ curcumin, and $30 \mu \mathrm{M}-\mathrm{CUR}-\mathrm{MSNAP}$ for $72 \mathrm{~h}$. Cells were harvested and stained with $5 \mu \mathrm{L}$ of $10 \mu \mathrm{g} / \mathrm{mL}$ propidium iodide (PI) for $10 \mathrm{~min}$. The stained cells were analyzed in FACS (FC500, Beckman Coulter, Brea, CA, USA) and PI positive cells were gated in FL3. The forward scatter (FSC) and side scatter (SSC) was also analyzed simultaneously.

\section{Measurement of intracellular curcumin released from nanoparticles}

The concentration of curcumin released from CURMSNAP in MCF-7 cells was determined by nanodrop. Briefly, 20,000 cells were grown in 12 well plate and incubated with $30 \mu \mathrm{M}$ CUR-MSNAP ( $\mathrm{IC}_{50}$ value) and with standard curcumin (solubilized in ethanol) concentrations $(1,5,10,25,50 \mu \mathrm{M})$. After $72 \mathrm{~h}$, the cells were harvested and lysed with lysis buffer (Tris $\mathrm{pH} 10,150 \mathrm{mM} \mathrm{NaCl}$, $10 \% \mathrm{DMSO}$ ) for $30 \mathrm{~min}$. and the lysate was sheared with 25 gauge needles followed by centrifugation at 12,000 rpm for $10 \mathrm{~min}$. at $4^{\circ} \mathrm{C}$. The supernatant was measured at $420 \mathrm{~nm}$ in nanodrop. The absorbance of curcumin was compared with standard curcumin graph.

\section{Western blot analysis}

The qualitative differences of CUR-MSNAP influenced protein expression in $\mathrm{MCF}-7$ cells were analyzed using Western blot. $2 \times 10^{6}$ cells grown in 100 $\mathrm{mm}$ dishes (Greiner) were treated with $50 \mu \mathrm{M}$ curcumin, $30 \mu \mathrm{g} / \mathrm{mL}$ MSNAP, $30 \mu \mathrm{M}$ CUR-MSNAP, and $15 \mu \mathrm{M}$ DTT for $72 \mathrm{~h}$. DTT was used as a positive control for UPR induction [61]. After incubation, MCF-7 cells were lysed with RIPA (Radio immunoprecipitation assay) buffer ( $\mathrm{pH}$ 7.4) containing protease and phosphatase cocktail inhibitors (Roche, Switzerland) on ice for $20 \mathrm{~min}$. and the lysates were sheared with 25 gauge needle, followed by centrifugation at $12,000 \mathrm{rpm}$ for $25 \mathrm{~min}$. at $4^{\circ} \mathrm{C}$. Proteins were quantified with BCA reagent (Sigma-Aldrich, St. Louis, MO). Each $50 \mu \mathrm{g}$ of proteins were loaded on SDS-PAGE and run at $110 \mathrm{~V}$ for $2 \mathrm{~h}$. The proteins were transferred to nitrocellulose membrane (Amersham Bioscience, Piscataway, NJ, USA). Anti-PERK, anti-IRE1 $\alpha$, anti-GRP 78, anticalnexin, anti-phospho-Akt (Ser473), anti-total Akt, anti-phospho PTEN (ser 380), anti-PARP, anti-caspase 12, anti-caspases 9, 6, anti-CHOP, and anti-GAPDH were obtained from Cell Signalling Technology (Danvers, MA, USA). The membrane was incubated overnight with primary antibodies at $4^{\circ} \mathrm{C}$ followed by either anti-rabbit IgG or anti-mouse IgG HRP-linked secondary antibodies (Santa Cruz, CA, USA) for 1 h. Presence of the protein was detected with addition of lumiglo (Thermo Scientific, Rockford, IL, USA) reagent and imaged in gel documentation system (BioRad, Hercules, CA, USA) with Image lab 5 software. Densitometry of respective bands was analyzed by Image $\mathrm{J}$ software. Expression of proteins was represented as fold change with a ratio of each protein to its loading control GAPDH.

\section{Analysing DOX-MSNAP induced cell death in MCF-7R cells}

Viability assay was performed on MCF-7R cells with DOX, DOX-MSNAP, CUR, and CUR-MSNAP as described earlier in 96 well plate. WST reagent was used to quantify the percentage of cell death and the concentration of DOX, DOX-MSNAP, CUR, CUR-MSNAP inducing $50 \%$ cell death was predicted. Flow cytometric analysis was also used to confirm the live and dead cells population in above-mentioned conditions.

\section{Docking studies}

Autodock 4.2 tool was used for docking curcumin with proteins caspase 3,9 , IRE $1 \alpha$, PERK, PARP, Akt1, and PTEN. The grid was built for $60 \times 60 \times 60$ in $\mathrm{X}, \mathrm{Y}$ $\& \mathrm{Z}$ directions. The binding model for each protein was analyzed with visualization tool PyMOL [62].

\section{Statistical analysis}

All experiments were repeated in three times. Results analyzed as the mean \pm standard error of the mean values. Statistical analysis of control group and treatment group was performed with student's $t$-test (Graph pad Prism 5, Graph pad software, San Diego, CA, USA). $P$ value of $<0.05$ was considered statistically significant with a $95 \%$ confidence interval.

\section{CONCLUSIONS}

In summary, non-spherical mesoporous silica nanoparticle coated with PEI was characterized for its drug delivery efficiency in MCF-7 cells. Influence of MCM-41P, MSNAP and CUR-MSNAP treated MCF-7 cells were summarized in Supplementary Figure 1. The non-spherical shape of MSNAP synthesized by origami method aids reduction in toxicity, faster intracellular accumulation, and better drug release. Drug released from MSNAP intracellularly even at lower concentration disturbs the cellular organelles and induce apoptosis. Additionally, MSNAP mediated drug delivery sensitized resistant cells at subordinate drug concentration. We report 
the mesoporous silica nanoparticle with non-spherical shape has to influence on cytotoxicity and drug delivery. Further in vivo exploitation of MSNAP will be helpful in understanding the biodistribution and bioavailability of this carrier particle.

\section{Abbreviations}

PEI: Polyethyleneimine; MCM-41P: MCM-41 coated with PEI; MSNAP: MSNA coated with PEI; CURMSNAP: Curcumin loaded MSNA coated with PEI; MSN: Mesoporous silica nanoparticles; $\mathrm{IC}_{50}$ : Inhibitory concentration (50\%); $\mathrm{LD}_{50}$ : Lethal dosage $(50 \%)$; DOXMSNAP/MCM-41P: Doxorubicin loaded MSNAP/MCM41P; DDS: Drug delivery system; CUR-DOX-MSNAP: Curcumin and Doxorubicin loaded MSNAP.

\section{ACKNOWLEDGMENTS AND FUNDING}

This study was supported in part by a seed grant from Kalasalingam Academy of Research and Education (KARE). Authors are acknowledging Dr. Chandrasekar Sagar, Mr. Ramesh and Mr. Sathish for their help in using the TEM facility at NIMHANS, Bangalore. Authors also thank Prof. S. Rajagopalan, Madurai Kamaraj University for his support. Authors also acknowledge Mr. B.S. Srinag's help in handling FACS and confocal microscope. Help on docking studies by Dr. Sentilkumar was also acknowledged.

\section{CONFLICTS OF INTEREST}

The authors declare that there are no conflicts of interest.

\section{REFERENCES}

1. Mamaeva V, Sahlgren C, Lindén M. Mesoporous silica nanoparticles in medicine-recent advances. Adv Drug Deliv Rev. 2013; 65:689-702. https://doi.org/10.1016/j. addr.2012.07.018.

2. Bharti C, Nagaich U, Pal AK, Gulati N. Mesoporous silica nanoparticles in target drug delivery system: A review. Int J Pharm Investig. 2015; 5:124-33. https://doi. org/10.4103/2230-973X.160844.

3. Mout R, Moyano DF, Rana S, Rotello VM. Surface functionalization of nanoparticles for nanomedicine. Chem Soc Rev. 2012; 41:2539-44. https://doi.org/10.1039/ c2cs15294k.

4. Amoozgar Z, Yeo Y. Recent advances in stealth coating of nanoparticle drug delivery systems. Wiley Interdiscip Rev Nanomed Nanobiotechnol. 2012; 4:219-33. https://doi. org/10.1002/wnan.1157.

5. Xia T, Kovochich M, Liong M, Meng H, Kabehie S, George S, Zink JI, Nel AE. Polyethyleneimine coating enhances the cellular uptake of mesoporous silica nanoparticles and allows safe delivery of siRNA and DNA constructs. ACS Nano. 2009; 3:3273-86. https://doi.org/10.1021/nn900918w.

6. Benjaminsen RV, Mattebjerg MA, Henriksen JR, Moghimi SM, Andresen TL. The possible "proton sponge" effect of polyethylenimine (PEI) does not include change in lysosomal pH. Mol Ther. 2013; 21:149-57. https://doi. org/10.1038/mt.2012.185.

7. Clemens DL, Lee BY, Xue M, Thomas CR, Meng H, Ferris D, Nel AE, Zink JI, Horwitz MA. Targeted intracellular delivery of antituberculosis drugs to Mycobacterium tuberculosisinfected macrophages via functionalized mesoporous silica nanoparticles. Antimicrob Agents Chemother. 2012; 56:2535-45. https://doi.org/10.1128/AAC.06049-11.

8. Truong NP, Whittaker MR, Mak CW, Davis TP. The importance of nanoparticle shape in cancer drug delivery. Expert Opin Drug Deliv. 2015; 12:129-42. https://doi.org/1 $0.1517 / 17425247.2014 .950564$.

9. Zhao J, Lu H, Wong S, Lu M, Xiao P, Stenzel MH. Influence of nanoparticle shapes on cellular uptake of paclitaxelloaded nanoparticles in 2D and 3D cancer models. Polym Chem. 2017; 8:3317-26. https://doi.org/10.1039/ C7PY00385D.

10. Forest V, Leclerc L, Hochepied JF, Trouvé A, Sarry G, Pourchez J. Impact of cerium oxide nanoparticles shape on their in vitro cellular toxicity. Toxicol In Vitro. 2017; 38:136-41. https://doi.org/10.1016/j.tiv.2016.09.022.

11. Fu PP, Xia Q, Hwang HM, Ray PC, Yu H. Mechanisms of nanotoxicity: generation of reactive oxygen species. J Food Drug Anal. 2014; 22:64-75. https://doi.org/10.1016/j. jfda.2014.01.005.

12. Hao N, Yang H, Li L, Li L, Tang F. The shape effect of mesoporous silica nanoparticles on intracellular reactive oxygen species in A375 cells. New J Chem. 2014; 38:425866. https://doi.org/10.1039/C4NJ00736K.

13. Li L, Liu T, Fu C, Tan L, Meng X, Liu H. Biodistribution, excretion, and toxicity of mesoporous silica nanoparticles after oral administration depend on their shape. Nanomedicine (Lond). 2015; 11:1915-24. https://doi. org/10.1016/j.nano.2015.07.004.

14. Gera M, Sharma N, Ghosh M, Huynh DL, Lee SJ, Min T, Kwon T, Jeong DK. Nanoformulations of curcumin: an emerging paradigm for improved remedial application. Oncotarget. 2017; 8:66680-98. https://doi.org/10.18632/ oncotarget.19164.

15. Naksuriya O, Okonogi S, Schiffelers RM, Hennink WE. Curcumin nanoformulations: a review of pharmaceutical properties and preclinical studies and clinical data related to cancer treatment. Biomaterials. 2014; 35:3365-83. https:// doi.org/10.1016/j.biomaterials.2013.12.090.

16. Wang $\mathrm{S}$, Tan $\mathrm{M}$, Zhong $\mathrm{Z}$, Chen $\mathrm{M}$, Wang $\mathrm{Y}$. Nanotechnologies for curcumin: an ancient puzzler meets modern solutions. J Nanomater. 2011; 2011:1-8. https://doi. org/10.1155/2011/723178.

17. Bansal SS, Goel M, Aqil F, Vadhanam MV, Gupta RC. Advanced drug delivery systems of curcumin for cancer 
chemoprevention. Cancer Prev Res (Phila). 2011; 4:1158-71. https://doi.org/10.1158/1940-6207.CAPR-10-0006.

18. Bravo-Sagua R, Rodriguez AE, Kuzmicic J, Gutierrez T, Lopez-Crisosto C, Quiroga C, Díaz-Elizondo J, Chiong M, Gillette TG, Rothermel BA, Lavandero S. Cell death and survival through the endoplasmic reticulum-mitochondrial axis. Curr Mol Med. 2013; 13:317-29. https://doi. org/10.2174/156652413804810781.

19. D'Souza GG, Wagle MA, Saxena V, Shah A. Approaches for targeting mitochondria in cancer therapy. Biochim Biophys Acta. 2011; 1807:689-96. https://doi.org/10.1016/j. bbabio.2010.08.008.

20. Ma'mani L, Nikzad S, Kheiri-Manjili H, Al-Musawi S, Saeedi M, Askarlou S, Foroumadi A, Shafiee A. Curcumin-loaded guanidine functionalized PEGylated I3ad mesoporous silica nanoparticles KIT-6: practical strategy for the breast cancer therapy. Eur J Med Chem. 2014; 83:646-54. https://doi.org/10.1016/j.ejmech.2014.06.069.

21. Khosropanah MH, Dinarvand A, Nezhadhosseini A, Haghighi A, Hashemi S, Nirouzad F, Khatamsaz S, Entezari M, Hashemi M, Dehghani H. Analysis of the Antiproliferative Effects of Curcumin and Nanocurcumin in MDA-MB231 as a Breast Cancer Cell Line. Iran J Pharm Res. 2016; 15:231-39.

22. Kotcherlakota R, Barui AK, Prashar S, Fajardo M, Briones D, Rodríguez-Diéguez A, Patra CR, Gómez-Ruiz S. Curcumin loaded mesoporous silica: an effective drug delivery system for cancer treatment. Biomater Sci. 2016; 4:448-59. https://doi.org/10.1039/C5BM00552C.

23. Harini L. Theranostic application of curcumin loaded mesoporous silica nanoparticle in breast adenocarcinima cell lines (MCF-7), Kalasalingam university, Ph.D thesis. 2016.

24. Tang F, Li L, Chen D. Mesoporous silica nanoparticles: synthesis, biocompatibility and drug delivery. Adv Mater. 2012; 24:1504-34. https://doi.org/10.1002/adma.201104763.

25. Roggers R, Kanvinde S, Boonsith S, Oupický D. The practicality of mesoporous silica nanoparticles as drug delivery devices and progress toward this goal. AAPS PharmSciTech. 2014; 15:1163-71. https://doi.org/10.1208/ s12249-014-0142-7.

26. Cho Y, Shi R, Borgens RB, Ivanisevic A. Functionalized mesoporous silica nanoparticle-based drug delivery system to rescue acrolein-mediated cell death. Nanomedicine (Lond). 2008; 3:507-19. https://doi.org/10.2217/17435889.3.4.507.

27. Clifford NW, Iyer KS, Raston CL. Encapsulation and controlled release of nutraceuticals using mesoporous silica capsules. J Mater Chem. 2008; 18:162-65. https://doi. org/10.1039/B715100D.

28. Tutuianu R, Popescu LM, Preda MB, Rosca AM, Piticescu RM, Burlacu A. Evaluation of the ability of nanostructured PEI-coated iron oxide nanoparticles to incorporate cisplatin during synthesis. Nanomaterials (Basel). 2017; 7:E314. https://doi.org/10.3390/nano7100314.

29. Lin Y, Yan Q, Kong C, Chen L. Polyethyleneimine incorporated metal-organic frameworks adsorbent for highly selective CO2 capture. Sci Rep. 2013; 3:1859. https://doi.org/10.1038/srep01859.

30. Chou MJ, Yu HY, Hsia JC, Chen YH, Hung TT, Chao HM, Chern E, Huang YY. Highly efficient intracellular protein delivery by cationic polyethyleneimine-modified gelatin nanoparticles. Materials (Basel). 2018; 11:E301. https://doi. org/10.3390/ma11020301.

31. Hoare HR, Kohane DS. Hydrogels in drug delivery: progress and challenges. Polymer (Guildf). 2008; 49:19932007. https://doi.org/10.1016/j.polymer.2008.01.027.

32. Rezvani Amin Z, Rahimizadeh M, Eshghi H, Dehshahri A, Ramezani M. The effect of cationic charge density change on transfection efficiency of polyethylenimine. Iran J Basic Med Sci. 2013; 16:150-56.

33. Harini L, Karthikeyan B, Srivastava S, Suresh SB, Ross C, Gnanakumar G, Rajagopal S, Sundar K, Kathiresan T. Polyethylenimine-modified curcumin-loaded mesoporus silica nanoparticle (MCM-41) induces cell death in MCF-7 cell line. IET Nanobiotechnol. 2017; 11:57-61. https://doi. org/10.1049/iet-nbt.2016.0075.

34. Mathieu J. Interactions between autophagy and bacterial toxins: targets for therapy? Toxins (Basel). 2015; 7:2918 58. https://doi.org/10.3390/toxins7082918.

35. Petrache Voicu SN, Dinu D, Sima C, Hermenean A, Ardelean A, Codrici E, Stan MS, Zărnescu O, Dinischiotu A. Silica nanoparticles induce oxidative stress and autophagy but not apoptosis in the MRC-5 cell line. Int $\mathrm{J}$ Mol Sci. 2015; 16:29398-416. https://doi.org/10.3390/ ijms 161226171 .

36. Wang L, Liu Y, Li W, Jiang X, Ji Y, Wu X, Xu L, Qiu Y, Zhao K, Wei T, Li Y, Zhao Y, Chen C. Selective targeting of gold nanorods at the mitochondria of cancer cells: implications for cancer therapy. Nano Lett. 2011; 11:77280. https://doi.org/10.1021/nl103992v.

37. Yameen B, Choi WI, Vilos C, Swami A, Shi J, Farokhzad OC. Insight into nanoparticle cellular uptake and intracellular targeting. J Control Release. 2014; 190:48599. https://doi.org/10.1016/j.jconrel.2014.06.038.

38. Kim B, Kim HS, Jung EJ, Lee JY, K Tsang B, Lim JM, Song YS. Curcumin induces ER stress-mediated apoptosis through selective generation of reactive oxygen species in cervical cancer cells. Mol Carcinog. 2016; 55:918-28. https://doi.org/10.1002/mc.22332.

39. Misra J, Chanda D, Kim DK, Li T, Koo SH, Back SH, Chiang JY, Choi HS. Curcumin differentially regulates endoplasmic reticulum stress through transcriptional corepressor SMILE (small heterodimer partner-interacting leucine zipper protein)-mediated inhibition of CREBH (cAMP responsive element-binding protein $\mathrm{H}$ ). J Biol Chem. 2011; 286:41972-84. https://doi.org/10.1074/jbc. M111.274514.

40. Wen S, Zhu D, Huang P. Targeting cancer cell mitochondria as a therapeutic approach. Future Med Chem. 2013; 5:5367. https://doi.org/10.4155/fmc.12.190. 
41. Sano R, Reed JC. ER stress-induced cell death mechanisms. Biochim Biophys Acta. 2013; 1833:3460-70. https://doi. org/10.1016/j.bbamcr.2013.06.028

42. Georgescu MM. PTEN tumor suppressor network in PI3KAkt pathway control. Genes Cancer. 2010; 1:1170-77. https://doi.org/10.1177/1947601911407325.

43. McIlwain DR, Berger T, Mak TW. Caspase functions in cell death and disease. Cold Spring Harb Perspect Biol. 2013; 5:a008656. https://doi.org/10.1101/cshperspect.a008656.

44. Cullen SP, Martin SJ. Caspase activation pathways: some recent progress. Cell Death Differ. 2009; 16:935-38. https:// doi.org/10.1038/cdd.2009.59.

45. Breckenridge DG, Germain M, Mathai JP, Nguyen M, Shore GC. Regulation of apoptosis by endoplasmic reticulum pathways. Oncogene. 2003; 22:8608-18. https:// doi.org/10.1038/sj.onc. 1207108 .

46. Wang Y, Zhou L, Xiao M, Sun ZL, Zhang CY. Nanomedicine-based paclitaxel induced apoptotic signaling pathways in A562 leukemia cancer cells. Colloids Surf B Biointerfaces. 2017; 149:16-22. https://doi.org/10.1016/j. colsurfb.2016.08.022

47. Hussain SR, Lucas DM, Johnson AJ, Lin TS, Bakaletz AP, Dang VX, Viatchenko-Karpinski S, Ruppert AS, Byrd JC, Kuppusamy P, Crouser ED, Grever MR. Flavopiridol causes early mitochondrial damage in chronic lymphocytic leukemia cells with impaired oxygen consumption and mobilization of intracellular calcium. Blood. 2008; 111:3190-99. https://doi.org/10.1182/ blood-2007-10-115733.

48. Frey TG, Sun MG. Correlated light and electron microscopy illuminates the role of mitochondrial inner membrane remodeling during apoptosis. Biochim Biophys Acta. 2008; 1777:847-52. https://doi.org/10.1016/j.bbabio.2008.05.011.

49. Sun MG, Williams J, Munoz-Pinedo C, Perkins GA, Brown JM, Ellisman MH, Green DR, Frey TG. Correlated three-dimensional light and electron microscopy reveals transformation of mitochondria during apoptosis. Nat Cell Biol. 2007; 9:1057-65. https://doi.org/10.1038/ncb1630.

50. Shen ZY, Shen J, Li QS, Chen CY, Chen JY, Yi Z. Morphological and functional changes of mitochondria in apoptotic esophageal carcinoma cells induced by arsenic trioxide. World J Gastroenterol. 2002; 8:31-35. https://doi. org/10.3748/wjg.v8.i1.31.

51. Carneiro ML, Porfírio EP, Otake AH, Chammas R, Báo SN, Guillo LA. Morphological alterations and G0/G1 cell cycle arrest induced by curcumin in human SK-MEL-37 melanoma cells. Braz Arch Biol Technol. 2010; 53:343-52. https://doi.org/10.1590/S1516-89132010000200013.
52. Lv ZD, Liu XP, Zhao WJ, Dong Q, Li FN, Wang HB, Kong B. Curcumin induces apoptosis in breast cancer cells and inhibits tumor growth in vitro and in vivo. Int J Clin Exp Pathol. 2014; 7:2818-24.

53. Potokar M, Milisav I, Kreft M, Stenovec M, Zorec R. Apoptosis triggered redistribution of caspase-9 from cytoplasm to mitochondria. FEBS Lett. 2003; 544:153-59. https://doi.org/10.1016/S0014-5793(03)00494-0.

54. Guerrero AD, Schmitz I, Chen M, Wang J. Promotion of Caspase Activation by Caspase-9-mediated Feedback Amplification of Mitochondrial Damage. J Clin Cell Immunol. 2012; 3. https://doi.org/10.4172/2155-9899.1000126.

55. Srivastava A, Amreddy N, Babu A, Panneerselvam J, Mehta M, Muralidharan R, Chen A, Zhao YD, Razaq M, Riedinger N, Kim H, Liu S, Wu S, et al. Nanosomes carrying doxorubicin exhibit potent anticancer activity against human lung cancer cells. Sci Rep. 2016; 6:38541. https://doi.org/10.1038/srep38541.

56. Zahreddine H, Borden KL. Mechanisms and insights into drug resistance in cancer. Front Pharmacol. 2013; 4:28. https://doi.org/10.3389/fphar.2013.00028.

57. Lin G, Mi P, Chu C, Zhang J, Liu G. Inorganic nanocarriers overcoming multidrug resistance for cancer theranostics. Adv Sci (Weinh). 2016; 3:1600134. https://doi.org/10.1002/ advs.201600134.

58. Yuan Y, Cai T, Xia X, Zhang R, Chiba P, Cai Y. Nanoparticle delivery of anticancer drugs overcomes multidrug resistance in breast cancer. Drug Deliv. 2016; 23:3350-57. https://doi. org/10.1080/10717544.2016.1178825.

59. Kankala RK, Liu CG, Chen AZ, Wang SB, Xu PY, Mende LK, Liu CL, Lee $\mathrm{CH}, \mathrm{Hu}$ YF. Overcoming Multidrug Resistance through the Synergistic Effects of Hierarchical pH-Sensitive, ROS-Generating Nanoreactors. ACS Biomater Sci Eng. 2017; 3:2431-42. https://doi. org/10.1021/acsbiomaterials. 7b00569.

60. Smith L, Watson MB, O'Kane SL, Drew PJ, Lind MJ, Cawkwell L. The analysis of doxorubicin resistance in human breast cancer cells using antibody microarrays. Mol Cancer Ther. 2006; 5:2115-20. https://doi. org/10.1158/1535-7163.MCT-06-0190.

61. Dicks N, Gutierrez K, Michalak M, Bordignon V, Agellon LB. Endoplasmic reticulum stress, genome damage, and cancer. Front Oncol. 2015; 5:11. https://doi.org/10.3389/ fonc. 2015.00011

62. Hobani Y, Jerah A, Bidwai A. A comparative molecular docking study of curcumin and methotrexate to dihydrofolate reductase. Bioinformation. 2017; 13:63-66. https://doi.org/10.6026/97320630013063. 